\title{
A new species of Hydrochoerus (Rodentia: Caviidae: Hydrochoerinae) from the Pleistocene of San Diego County, California, USA with remarks on capybara biogeography and dispersal in the Pleistocene of Western North America
}

\author{
Richard S. White ${ }^{1^{*}}$, Jim I. Mead ${ }^{1,2}$, Thomas A. Deméré ${ }^{3}$, and Gary S. Morgan ${ }^{4}$ \\ ${ }^{1}$ The Mammoth Site, Hot Springs, South Dakota, USA 57747; RSWhite@mammothsite.org \\ ${ }^{2}$ Desert Laboratory on Tumamoc Hill, University of Arizona, Tucson, Arizona, USA 85745 \\ ${ }^{3}$ San Diego Natural History Museum, San Diego, California, USA 92112 \\ ${ }^{4}$ New Mexico Museum of Natural History and Science, Albuquerque, New Mexico, USA 87104
}

\begin{abstract}
We describe a new species of capybara from late Pleistocene deposits (Rancholabrean NALMA) in northern San Diego County, California, USA which tentatively dates to Marine Isotope Stage (MIS) 5 interglacial $(\sim 130 \mathrm{ka}$ to $80 \mathrm{ka})$. The specimen represents a new species of Hydrochoerus based on morphological characters of the upper incisor (I1) and the upper (maxillary) third molar (M3). Hydrochoerus hesperotiganites sp. nov. differs from other described species of Hydrochoerus in its larger size, wider skull roof, more robust zygomatic process of the maxilla and descending zygomatic process of the lacrimal and in details of the otic region. The new species is the only confirmed record of fossil Hydrochoerus in North America and is the northwestern-most record of any capybara in North America. All previous records of fossil capybara from North America represent one of two extinct genera, Neochoerus or Phugatherium. Northward dispersal of capybaras from central and southern México probably occurred along the coasts of Sinaloa and Sonora, entering the north or northeast flowing drainages which entered the Gulf of California, then further north into the San Simon drainage to the Gila River and ultimately into the Colorado River, or directly northward along the coast of Sonora to the mouth of the Colorado River.
\end{abstract}

lsid: urn:lsid:zoobank.org:pub:BD2DA9EB-32EF-4761-8551-E585D6AF317C

\section{INTRODUCTION}

Three genera of capybaras (Caviidae: Hydrochoerinae: Phugatherium, Neochoerus and Hydrochoerus, the latter being today's largest living rodent) dispersed into North America after the establishment of the Panama Land Bridge about $5 \mathrm{Ma}$ (Morgan 2008; Woodburne 2010; O'Dea et al. 2016). Phugutherium was present in central México by the Pliocene (early Blancan NALMA) at 3.6 Ma (Vucetich et al. 2015). Neochoerus is found in southern México in the Rancholabrean NALMA (CarbotChanona et al. 2020) and in Central México in the early Blancan at 3.5 Ma. These are the oldest verified record of any capybara in North America (Carranza-Castañeda and Miller 1988). Neochoerus has also been recorded from northern México in the Irvingtonian NALMA, as well as from the United States in the middle Blancan of South Carolina (Sanders 2002; Albright et al. 2019) and in the late Blancan through Rancholabrean in Florida and the Rancholabrean in Texas (Morgan and White 1995; Morgan 2005; Baskin et al. 2020). Hydrochoerus has been thought to have been present from the late Pliocene (late Blancan) to the latest Pleistocene (Rancholabrean) in the United States, but not in the Recent (Ahearn 1981; Morgan 2005). The fact that the earliest records of Neochoerus in North American are in the north rather than the south would seem to suggest that its origin was in the north; but the relative lack of fossil producing 
localities of appropriate age in southern México and Central America has likely produced a skewed record. The taxonomy and affinities of the two lineages (Phugatherium and Neochoerus + Hydrochoerus) were the subject of much research in the last decade (Vucetich et al. 2013; Vucetich et al. 2015; Carranza-Castañeda 2016; Albright et al. 2019; Baskin et al. 2020; Carbot-Chanona et al. 2020). Fossils of capybaras from North America previously allocated to the extant genus Hydrochoerus have subsequently been referred to Neochoerus, leaving Neochoerus and Phugatherium as the only capybaras known in the North American fossil record (Ahearn 1981; Mones 1991). Capybaras reached as far north and east as Florida and South Carolina, and as far north and west as Texas, Arizona, and Sonora, México (Ahearn 1981; Sanders 2002; Baskin et al. 2020; Mead et al. 2006). The Colorado River seems to have been a barrier beyond which capybaras and glyptodonts (Cingulata: Glyptodontinae) did not extend in the Pliocene or Pleistocene (Morgan 2008). The western-most occurrence of Glyptotherium texanum the Blancan and Irvingtonian species, is in Arizona, while the western-most occurrences of $G$. floridanum, or any Rancholabrean species, are in central Texas (Kurtén and Anderson 1980) and in Sonora, Mexico (Mead et al. 2007. One capybara specimen has been collected from extreme northwestern Sonora, México. However, that specimen, found in the early Irvingtonian locality of El Golfo, in deltaic deposits of the ancestral Colorado River (Lindsay 1984; Croxen et al. 2007; Carranza-Castańeda 2016) may have floated down from drainages to the north and east. Here we present the discovery of a nearly complete although badly crushed skull of a capybara collected in 1994 from upper Pleistocene lacustrine deposits in the San Luis Rey River Valley in San Diego County, California, USA. This specimen (SDSNH 50000) provides an opportunity to re-examine the evolution, historical biogeography, and dispersal of capybaras in North America.

Previous work: For the purposes of the present study, we adopt the taxonomic classification of capybaras proposed by Vucetich et al. $(2013,2014,2015)$ and followed in the three most recent papers on North American (NA) capybaras (Albright et al. 2019; Baskin et al. 2020; Carbot-Chanona et al. 2020). Two lineages with a total of three genera are recognized by Vucetich et al. (2015): (1) Phugatherium, with $P$. dichroplax as the only NA species; and (2) a lineage consisting of Neochoerus, with the NA species $N$. aesopi; and a Central and South American sister taxon, Hydrochoerus, including the extant $H$. hydrochaeris and $H$. isthmius.

The diminutive capybara $H$. isthmius was described by Goldman (1912) from six specimens collected in eastern Panama. Cabrera (1961) considered H. isthmius as only subspecifically distinct from $H$. hydrochaeris and this tax- onomy was followed by subsequent authors. Mones (1991), however, noted that the two species were clearly separable based on cranial measurements of 17 specimens of $H$. isthmius. Aeschbach et al. (2016) made a detailed analysis of ontogenetic changes in cranial size and morphology of both species based on 44 specimens of $H$. isthmius and 171 of $H$. hydrochaeris, demonstrating that the two are morphologically distinct. We follow recent authors (Ahearn 1981; Mones 1991; Baskin et al. 2020) in considering the fossil taxon $H$. holmesi to be properly allocated to Neochoerus.

One additional fossil species of Hydrochoerus (H. gaylordi) has been described by MacPhee et al. (2000) from Pliocene deposits on the island of Grenada at the southern end of the Lesser Antilles, about $160 \mathrm{~km}$ (100 miles) off the coast of Venezuela. We do not consider this species further here, as it is based on a partial right maxilla with M1-3 and diagnosed by a single character of the M2. We observe that the M2 of neonate extant Hydrochoerus have the two prisms on M2 united buccally as in $H$. gaylordi; by the age of 4 weeks the two laminae are separate as in the adults (Mones 1991: fig. $7 \mathrm{~A}, \mathrm{~B})$. Thus, it is possible that the condition seen in the type and only specimen of $H$. gaylordi may be an individual neotenic variant. Should further specimens be found to have the same condition and given the insular occurrence (Grenada) of H. gaylordi, it would stand as a valid species.

\section{MATERIALS AND METHODS}

Catalogued specimens of extant Hydrochoerus hydrochaeris are in the comparative collections of The Mammoth Site, Hot Springs, South Dakota. Age classes are as defined by Ojasti (1973, 2011) and Gorosabel et al. (2017). Restrictions in access to museum collections due to COVID-19 prevented us from examining a larger sample of Hydrochoerus skulls. This was especially unfortunate in that skulls of the northern-most species of extant capybara, H. isthmius, were not available to us.

Abbreviations: ka, kilo annum; Ma, mega-annum; MSCC, Mammoth Site Comparative Collection, The Mammoth Site at Hot Springs, SD; NALMA, North American Land Mammal Age; SDSNH, San Diego Society of Natural History, San Diego, California. Descriptive terminology for the capybara skull and dentition (upper M2 and M3) discussed is presented in Figures 1 and 2. L, left; R, right.

\section{GEOLOGICAL AND CHRONOLOGICAL CONTEXT}

Geological context: The new fossil specimen described here was collected from SDSNH Locality 3775 by Bradford O. Riney on March 5, 1994, during paleonto- 


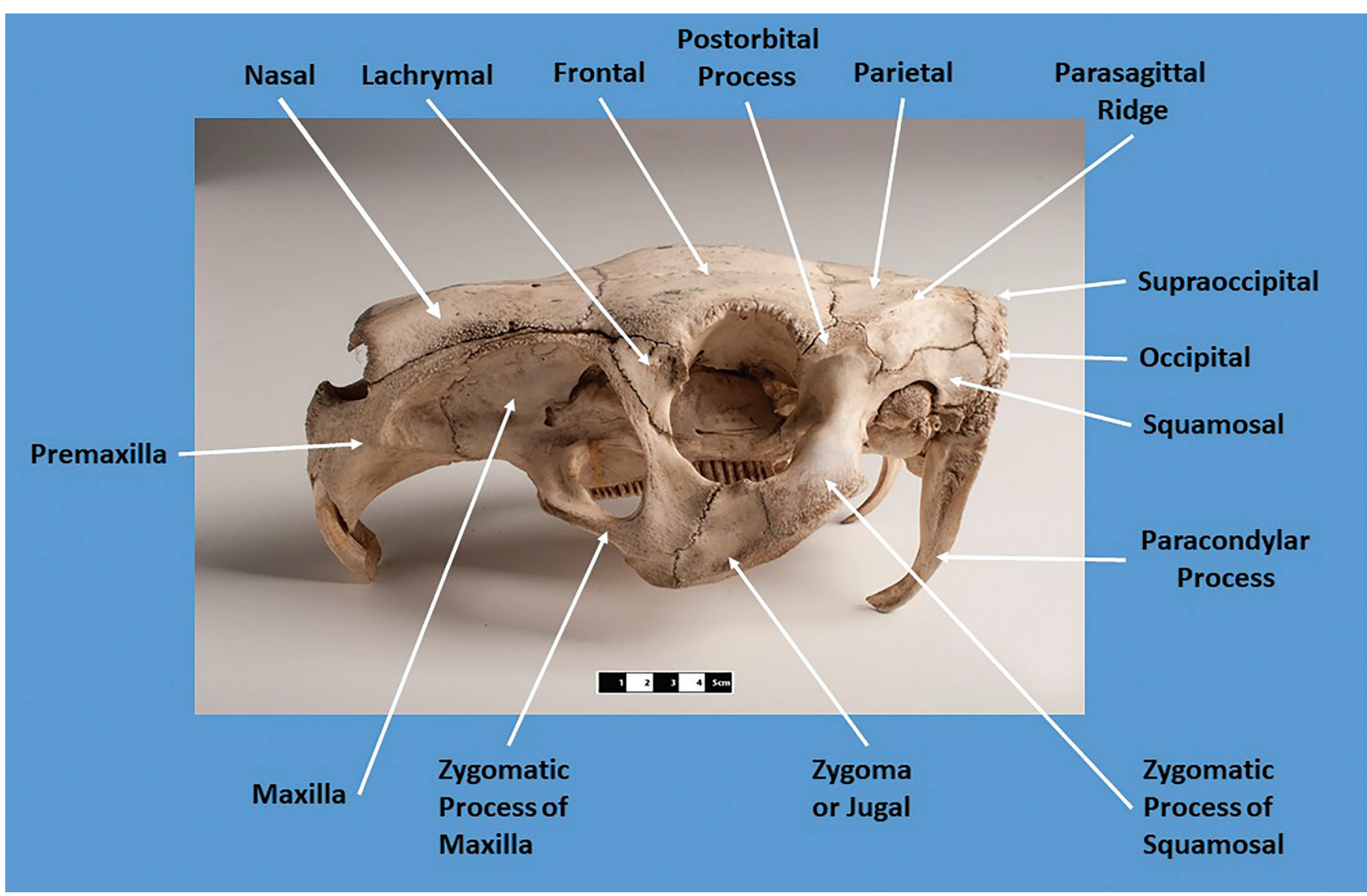

Figure 1. Cranial terminology utilized in this paper. Museum of Veterinary Anatomy FMVZ USP / Wagner Souza e Silva (https:// commons.wikimedia.org/wiki/File:Capybara_skull._Hydrochoerus_hydrochaeris_02.jpg), adding labels and arrows by Richard S. White, https: // creativecommons .org / licenses / by-sa / 4.0 / legalcode

logical mitigation monitoring of mass grading operations at the Town Center North shopping center in Oceanside, San Diego County, California, USA (Fig.3). The site is located on the south side of the San Luis Rey River Valley, a generally east-west trending coastal valley that preserves late Pleistocene invertebrate and vertebrate fossils from elevated and dissected river terrace deposits at a series of discovery sites along its length (Guthrie 2010; Deméré et al. 2013). At the Town Center North shopping center site, the Pleistocene stratigraphic sequence consisted of two distinct fluvial-lacustrine sequences (Fig. 4). The capybara fossil (SDSNH 50000) was collected from the lower (older) sequence, which consisted of up to $7.3 \mathrm{~m}$ (24 feet) of interbedded gray-green mudstones, laminated carbonaceous siltstones, and white to orange, friable medium- to coarse-grained graded sandstones with dispersed calcrete nodules. The skull was found palate up and collected from one of the gray-green mudstone beds, which also produced associated maxilla, mandibular, and dental fragmentary remains of an extinct pronghorn (cf. Stockoceros sp.) (Tab. 1). This lower lacustrine sequence was deposited along an irregular erosional surface cut into fluvial sandstones of the middle to upper Eocene Santiago Formation. In turn, an irregular erosional surface marks the upper contact between the older Pleistocene sedimentary sequence and an overlying younger Pleistocene sequence. This younger sequence consisted of up to $15.2 \mathrm{~m}$ of fluvial and lacustrine sediments beginning with a basal transgressive cross-bedded light gray sandstone gradationally overlain by $5.4 \mathrm{~m}$ of lacustrine green laminated mudstones and siltstones. The lacustrine deposits were overlain by $8.5 \mathrm{~m}$ of gray laminated and cross-laminated, fine-grained sandstones.

The basal cross-bedded sandstone produced a diverse aquatic assemblage of freshwater snails, clams, bony fishes, amphibians, and pond turtle, as well as a diverse terrestrial vertebrate assemblage of lizards, snakes, birds, and mammals (Tab. 1). Guthrie (2010) reported on the avifauna from this basal sandstone, which consists of over 19 species including grebes, pelican, ducks, rails, sandpiper, quail, roadrunner, and passerines. The dominance of the avifauna by waterfowl is consistent with the sedimentology and aquatic molluscan, fish, and turtle fossils also recovered from this stratum. The terrestrial mammal assemblage from the basal sandstone includes isolated skeletal elements of mole, rabbit, rodents, 

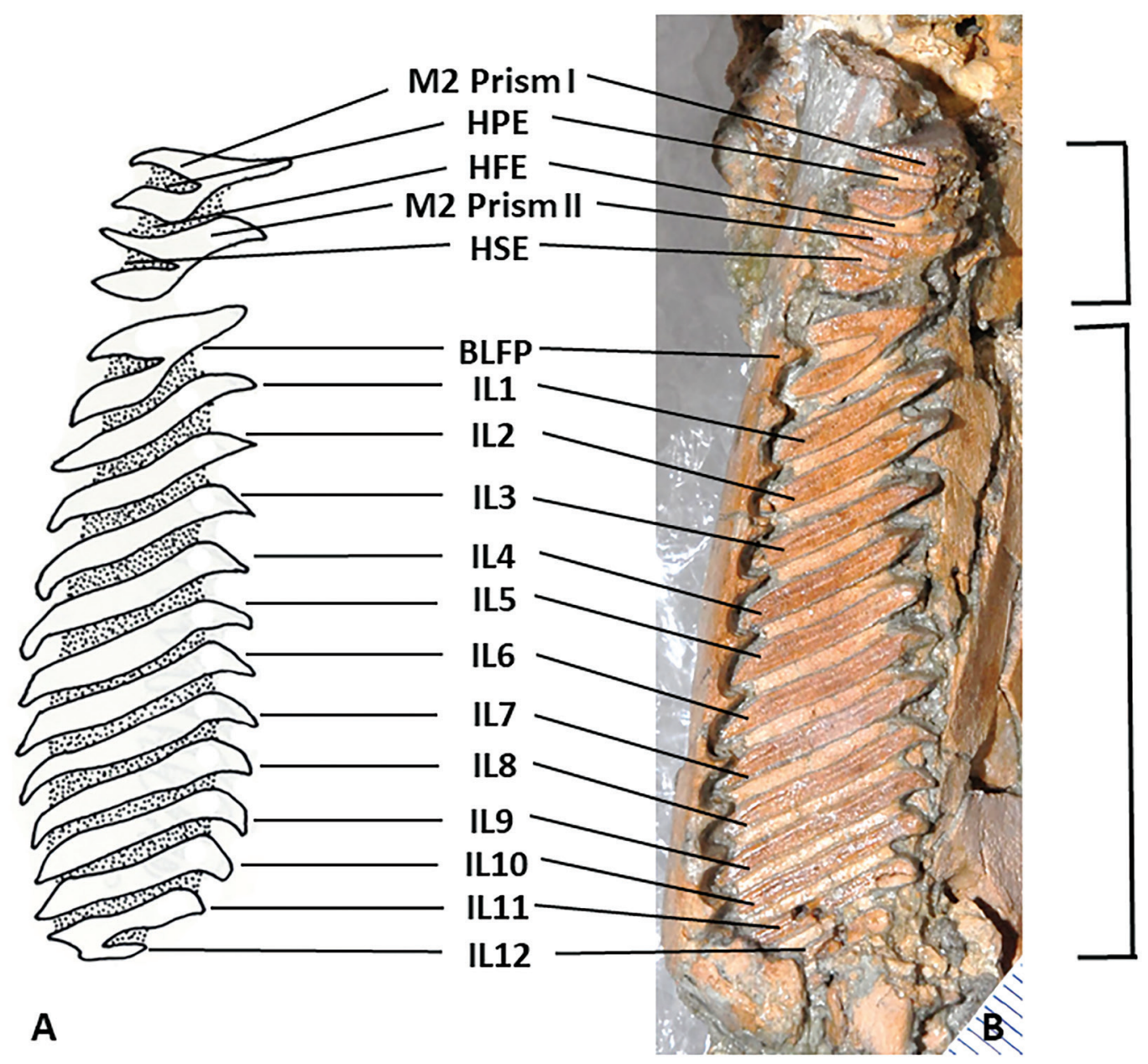

RM2

RM3

Figure 2. Dental terminology utilized in this paper. A, Hydrochoerus hydrochaeris after Mones (1991) : R M2 and M3 of SDSNH 50000. Abbreviations: RM2, second right upper molar; RM3, third right upper molar; HFE, Hendadura Fundamental Externa (Fundamental External Flexus); HPE, Hendadura Primeria Externa (Primary External Flexus); HSE, Hendadura Secundaria Externa (Secondary External Flexus); BLFP, BiLobed First Prism; IL1-12, Independent Prism 1-12.

fox, tapir, horse, mastodon, and ground sloths (Tab. 1). The overlying lacustrine laminated mudstones produced a much less diverse fossil assemblage that consisted of freshwater snails and clams, bony fishes, and horse, as well as leaf compressions of vascular plants including oak (Quercus sp.) and sycamore (Platanus sp.) (Tab. 1).

Depositional environment: The sedimentology and stratigraphy (Fig. 4) of the Town Center North Pleistocene sequence suggests deposition in a freshwater pond or oxbow lake on the southern margin of the ancestral San Luis Rey River Valley. The older lacustrine sequence preserving the capybara skull, although only exposed in a small area, appears to have been deposited on a relatively high relief unconformity eroded into older Eocene strata. This erosion surface likely formed as the ancestral San Luis Rey River was beginning to aggrade and deposit fine-grained sediments on its floodplain during a eustatic rise in sea level (i.e., an interglacial). The interbedded sequence of mud- stones, laminated carbonaceous siltstones, and medium- to coarse-grained graded sandstones likely represent seasonal changes in sediment input to this fluvial-lacustrine setting. The erosion surface that cuts the older Pleistocene lacustrine sequence is here interpreted to have formed as the river meandered back to the south during a later time of the same interglacial period. The basal cross-bedded sandstone resting on this unconformity likely represents a coarsegrained "beach" facies that was deposited as the floodplain was aggrading and another ox-bow lake was forming. The mixture of terrestrial and aquatic taxa in this basal transgressive unit and the occurrence of isolated and non-articulated skeletal elements suggests a possible scenario whereby bloated, floating mammalian carcasses were successively being "beached," shedding bones, and refloated. The gradational contact between the sandstone "beach" facies and the laminated mudstone-siltstone "lake" facies suggests continuous interglacial floodplain aggradation. 


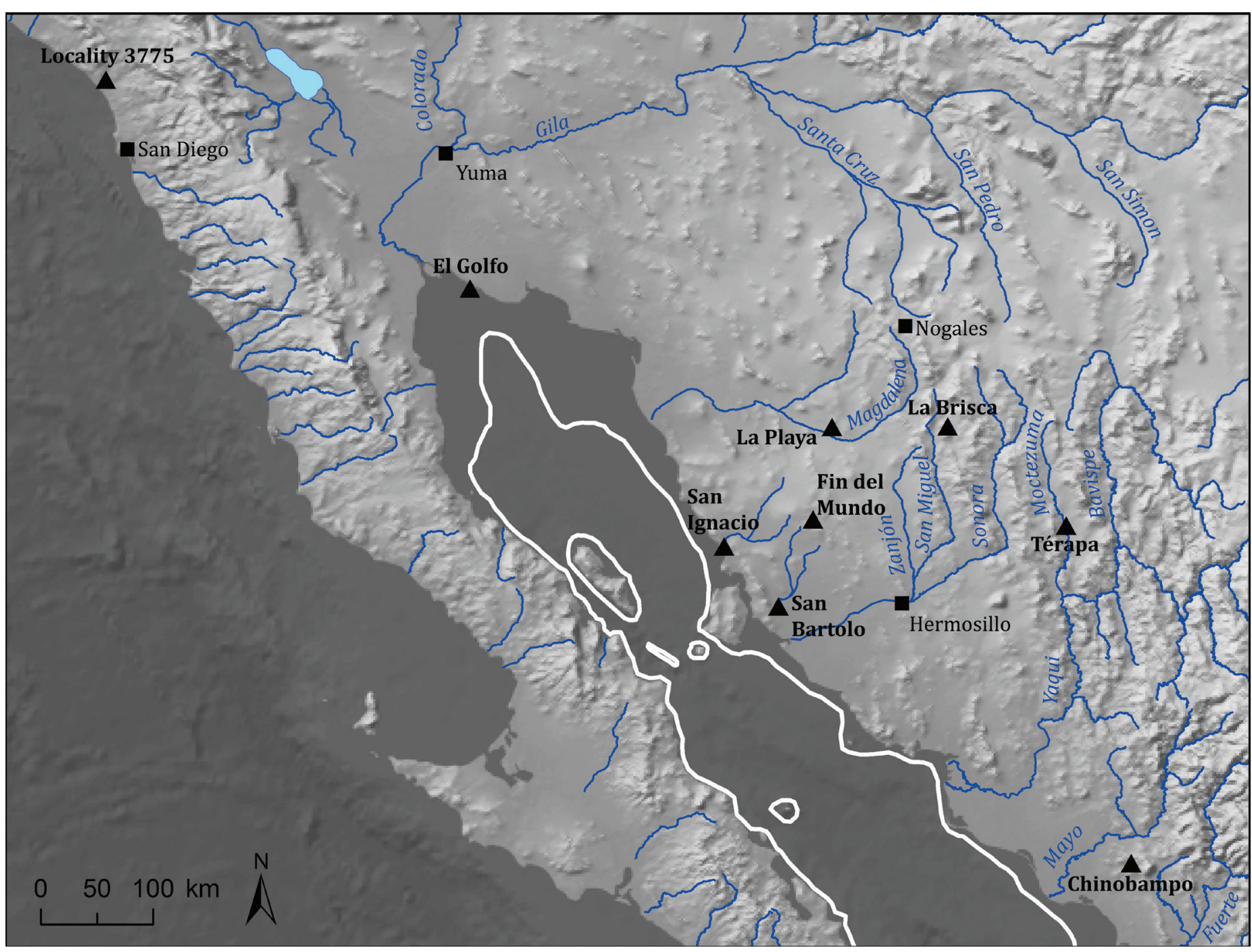

Figure 3. Map of northwestern México and southwestern United States, showing key cities for landmarks (solid square) and key paleontological sites mentioned in the text (solid triangles). Major river valleys indicated and labeled. Glacial maximum shoreline indicated by white line, based on bathymetry. The US/Mexico border is approximated by the location of San Diego, Yuma and Nogales. Map courtesy of Matthew C. Pailes, Department of Anthropology, University of Oklahoma.

Chronology: Unfortunately, none of the recovered fossils provide clear biochronological control concerning the age of the enclosing strata. Although no remains of Bison (an "index" fossil for the Rancholabrean NALMA) were recovered from these strata, there are a number of extinct mammalian taxa that typically occur in Rancholabrean age faunas of southern California (e.g., Mammut americanum, Megalonyx jeffersonii), or only in the Rancholabrean (Nothrotheriops shastensis). Further, fossils of Bison latifrons have been recovered from potentially correlative strata located in the San Luis Rey River Valley, approximately 18 $\mathrm{km}$ upstream from the Town Center North fossil localities (Deméré et al. 2013). Considering the fauna and strata together suggests that deposition of the Town Center North Pleistocene stratigraphic sequence occurred during an interglacial interval and most likely during the early Rancholabrean MIS 5 interglacial ( $\sim 130 \mathrm{ka}$ to $80 \mathrm{ka})$.

\section{SYSTEMATIC PALEONTOLOGY}

RODENTIA Bowdich, 1821

CAVIOIDEA Gray, 1821

CAVIIDAE Fisher, 1817

HYDROCHOERINAE Gray 1825

Hydrochoerus Brisson, 1762

Hydrochoerus hesperotiganites sp. nov.

Figures 2, 5, 6, 7

3D Animated Rendering

Holotype: SDSNH 50000, a nearly complete skull lacking mandible.

Type locality and horizon: SDSNH Locality 3775 , San Diego County, California, USA. The fauna and stratigraphy together suggest that deposition occurred during an interglacial interval and most likely during the early Rancholabrean MIS 5 interglacial ( $-130 \mathrm{ka}$ to $80 \mathrm{ka})$. 
Table 1. Faunal lists for the three depositional units producing fossils

Lower Lacustrine Unit Upper Lacustrine Unit (basal sandstone) Upper Lacustrine Unit (mudstone/siltstone)

Vertebrata

Mammalia

Hydrochoerus hesperotiganites cf. Stockoceros sp.
Mollusca

$$
\begin{aligned}
& \text { Gastropoda } \\
& \text { Physa sp. } \\
& \text { Fossaria sp. } \\
& \text { Gyraulus sp. } \\
& \text { Pelecypoda } \\
& \text { Anodonta sp. }
\end{aligned}
$$

Vertebrata

Osteichthyes

Mugilsp. cf. M. cephalus

Gila sp.

Gasterosteus sp.

Amphibia

Bufo sp.

Chelonia

Actinemys marmorata

Squamata

Thamnophis sp.

Colubridae

Aves

Aechmophorus occidentalis

Podilymbus podiceps

Podiceps parvus

Pelecanus erythrorhynchus

Aythya affinis

Bucephala albeola fossilis

Oxyura jamaicensis

Rallus limicola

Fulica americana

Phalaropus lobatus

Callipepla californica

Geococyx californicus

Aphelocoma californica

Vireo sp.

Toxostoma redivivum

Agelaius phoeniceus

Meospiza sp. cf. M. melodi

Mammalia

Talpidae

Sylvilagus sp. cf. S. auduboni

Thomomys sp.

Peromyscys sp.

Microtus sp. cf. M. californicus

Urocyon cinereoargenteus

Tapirus sp.

Equus sp.

Mammut americanum

Megalonyx jeffersonii

Nothrotheriops shastensis
Mollusca

$$
\begin{aligned}
& \text { Gastropoda } \\
& \text { Physa sp. }
\end{aligned}
$$

Pelecypoda Anodonta sp.

Vertebrata

Osteichthyes

Mugil sp. cf. M. cephalus

Gasterosteus sp.

Gobiidae
Mammalia

Equus sp.
Plantae

$$
\begin{aligned}
& \text { Tracheophyta } \\
& \text { Quercus sp. } \\
& \text { Platanus sp. }
\end{aligned}
$$




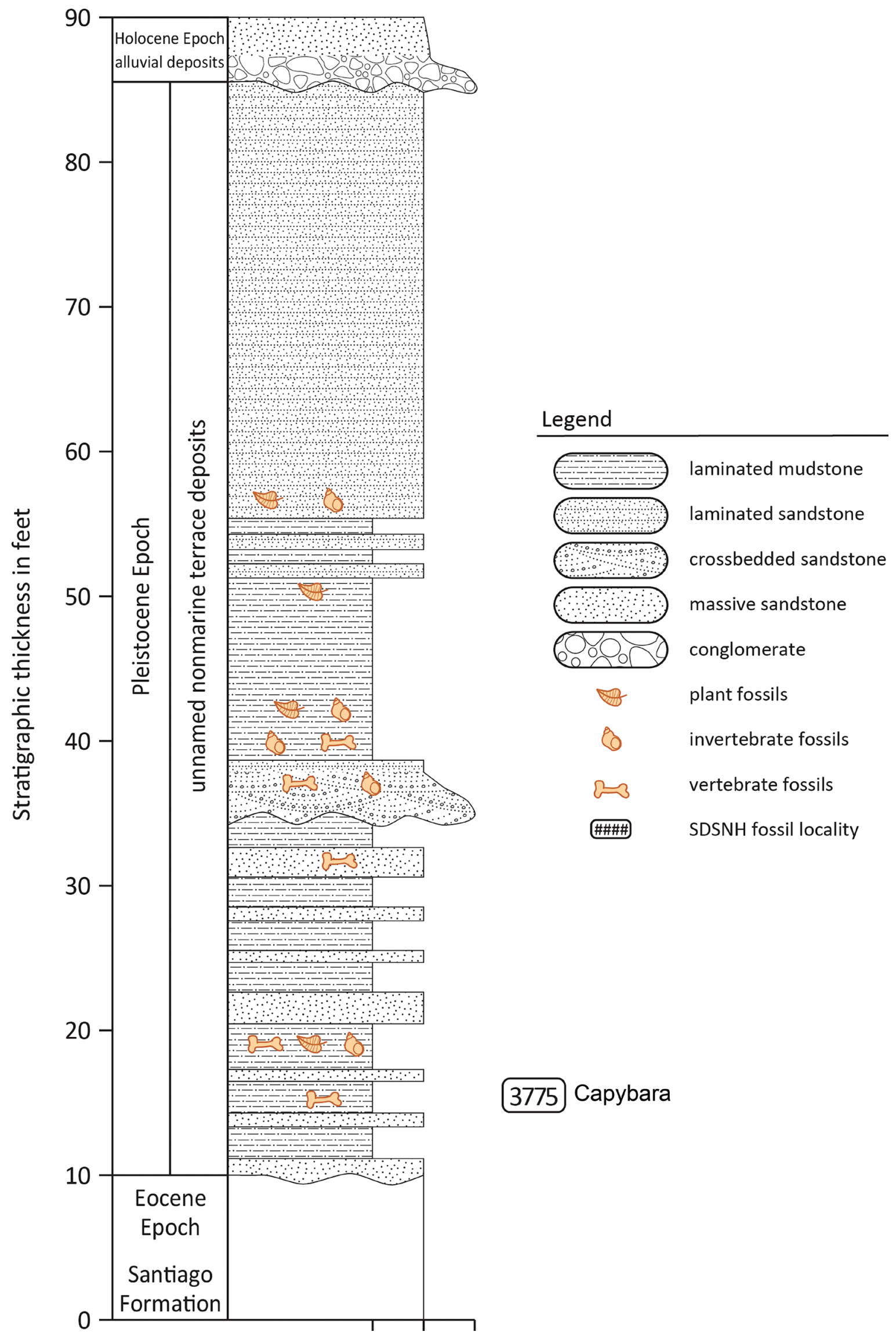

Figure 4. Stratigraphic section for SDSNH locality 3775 Oceanside, San Diego County, California, USA. 
Etymology: The specific epithet is from the Greek 'hesperos', meaning western, and the Greek 'tiganites', meaning pancake, in reference to its geographic location as the northwestern-most occurrence of a capybara in North America, as well as the crushed condition of the holotype.

Diagnosis: A hydrochoerine caviid rodent referred to Hydrochoerus because it has an anteriorly grooved upper incisor (I1) with faint striations within and lateral to the groove and an M3 with a Bi-Lobed First Prism (BLFP) followed by 12 independent prisms. It differs from other described species of Hydrochoerus in its larger size, wider skull roof, more robust zygomatic process of the maxilla, and more robust descending zygomatic process of the lacrimal. In the otic region, the anteromedial part of the petrosal reaches and overlaps the alisphenoid; in the extant species $H$. hydrochaeris the anterolateral process of the petrosal does not reach the alisphenoid because the rostral process of the malleus separates the two.

\section{DESCRIPTION}

\section{Skull}

SDSNH 50000 is a nearly complete, although badly crushed skull (Figs. 2, 5, 6, 7; link to 3D scan). To better reference the position of the structures described, as well as the direction and extent of distortion during crushing, we established the dorsal midline of the skull (Fig. 5A) as a line passing through the midline of the nasal bones and the midline of the occipital bone. Ventrally we established the midline as a line passing between the nasals, and the midline of the basisphenoid and basioccipital (Fig. 5C). Neither line is entirely straight, nor are the two lines congruent, due to the differential distortion of the ventral versus the dorsal aspect of the skull.

Dorsal view: In dorsal view (Fig. 5A, B), the skull seems relatively undeformed; the long axis of the specimen as preserved approximates the sagittal axis of the skull. The nasal, frontal, parietal, and occipital bones are present although fragmented. The condition of the naso-frontal and fronto-parietal sutures suggests that they were unfused; the parietal-occipital suture is clearly unfused. The left and right nasal bones are present, although only the right preserves the anterior margin. The maximum length of the right nasal is $87.8 \mathrm{~mm}$. The maximum width of the left nasal is $30.0 \mathrm{~mm}$ and the right nasal, $30.7 \mathrm{~mm}$. The left premaxilla is represented by two unattached fragments preserving portions of the incisor alveolus. The upper incisor can be accurately placed in anatomical position between these fragments, allowing visualization of the form of the left premaxilla. The dorsal premaxilla fragment preserves the ventrolateral margin of the external nares and a portion of the sharply defined nasal process of the premaxilla. The ventral premaxilla fragment preserves the medial surface of the intrapremaxillary suture, the anterolateral margin of the incisive foramen, and the ventrolateral external surface. Portions of the right maxilla are visible in dorsal view but badly fragmented. However, enough is preserved to allow the infraorbital canal to be visualized. As viewed anteriorly, the canal opening has the form of an acute triangle about $34.9 \mathrm{~mm}$ wide at the base. The preserved height of the canal is $46.3 \mathrm{~mm}$, but this represents only the dorsomedial height of the canal as measured on the lacrimal and not the maximum height as measured on the maxilla.

The frontals are badly fragmented; the right frontal more so than the left. Neither the fronto-nasal nor the fronto-parietal sutures are clearly visible; we interpret them as unfused, given the unfused condition of other cranial sutures. However, this cannot be determined definitively given the damaged nature of the specimen. The fronto-squamosal sutures are also unfused, as evidenced by the mortised sutural surface on the ascending processes of the squamosals that are elevated above the diagenetically depressed frontals. The dorsal surface of the frontals is planar and marked along the position of the completely fused interfrontal suture by several minute foramina. A slight sagittal ridge occurs behind the posterior-most foramen and extends $32.8 \mathrm{~mm}$ to the broken posterior margin. A portion of the right lacrimal is present, where it remains in articulation with the ascending process of the maxilla.

The dorsal surface of the fused parietals is also relatively planar and does not appear to slope ventrally towards its contact with the occipital, although this is difficult to judge given the crushed condition of the skull. There is no indication that an inter-parietal was present. Anteriorly, the lateral edges of the dorsal parietal table are bounded by sharply defined, medially convex parasagittal ridges, that mark the juncture of the lateral and horizontal surfaces of the parietal. These features have been referred to as the sagittal crest by Simpson (1930), although they are not a true sagittal crest, as they never unite at the midline. This same feature has also been termed the temporal line in suid crania (e.g., Doley et al. 2018). Hulbert et al. (2009) described a similar feature in Tapirus polkensis (Tapiridae), terming them parasagittal ridges; we follow this terminology. The parasagittal ridge extends from the occipito-parietal suture towards the fronto-parietal suture at the postorbital projection of the frontal. The posterior portion of each parasagittal ridge is sharply marked and produced into a ridge not more than $1 \mathrm{~mm}$ in height above the dorsal table. As the ridge extends further anteriorly toward the postorbital projection, it becomes lower and broader until it nearly disappears. The parasagittal ridges never unite to form a true sagittal crest; their closest approximation to each other is located $10.1 \mathrm{~mm}$ anterior to the occipito-parietal suture. The posterior width of the dorsal surface of the parietal table at its narrowest is $23.5 \mathrm{~mm}$. The parasagittal ridges are continu- 

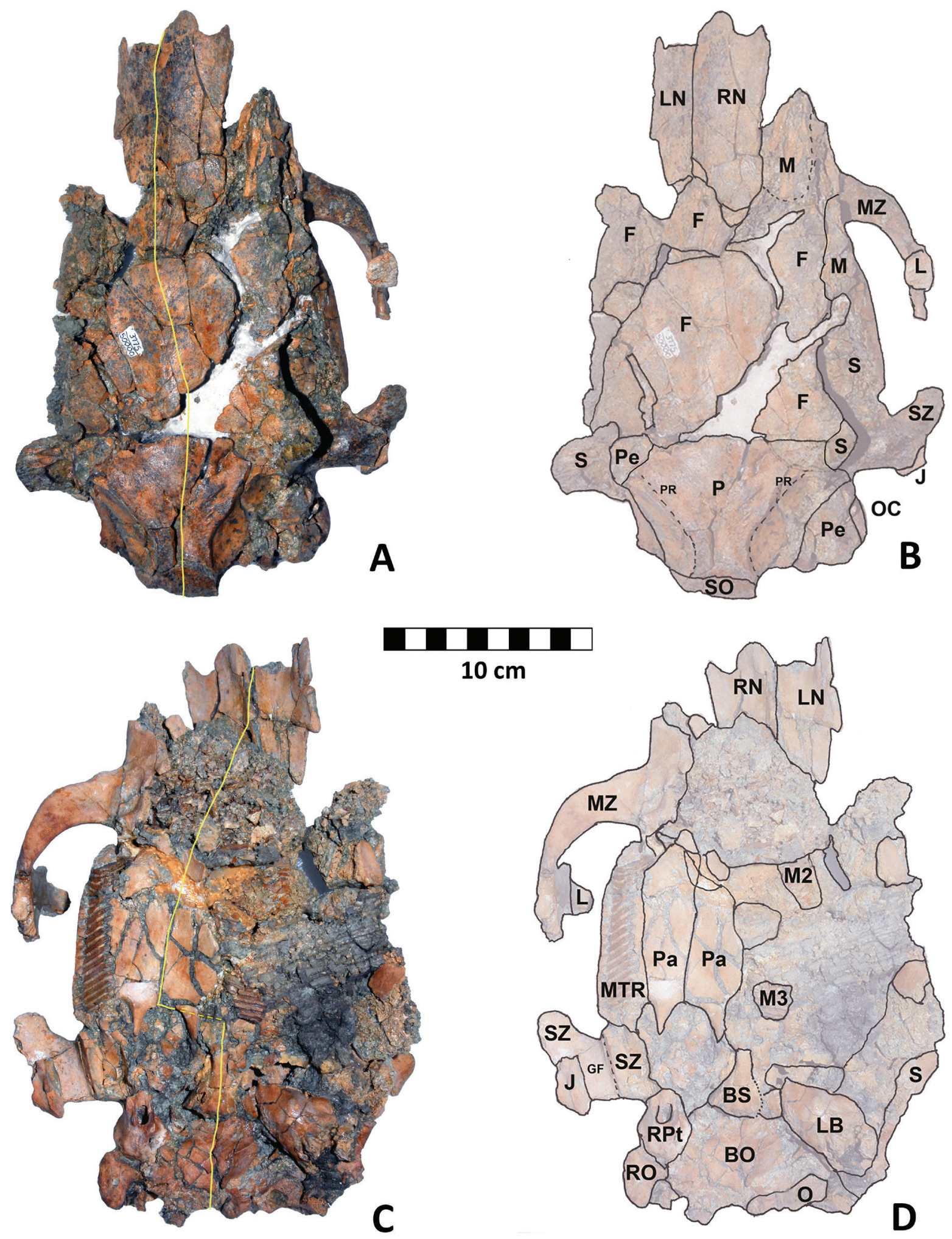

Figure 5. SDSNH 50000. A, B: dorsal view; C, D: ventral view. In B and D, the boundaries of the bones are approximations, as the crushed condition of the skull prevented determining actual suture lines in many cases. Abbreviations: BO, basioccipital; BS, basisphenoid; F, frontal; GF, glenoid fossa; J, jugal; L, lachrymal; LB, left auditory bulla; LN, left nasal; M, maxilla; MTR, maxillary tooth row; MZ, zygomatic process of maxilla; M2, fragment of second upper molar; M3, fragment of third upper molar; O, occipital; OC, occipital condyle; P, parietal; Pa, palatine; Pe, petrosal; PR, parasagittal ridge; RN, right nasal; RO, right occipital condyle; RPt, right petrosal; S, squamosal; SO, supraoccipital; SZ, zygomatic process of squamosal. Unlabeled areas are either fragments of bone which could not be allocated to a specific element, areas of crushed and comminuted bone, matrix, or are gaps between bones where fragments have separated or are missing. 

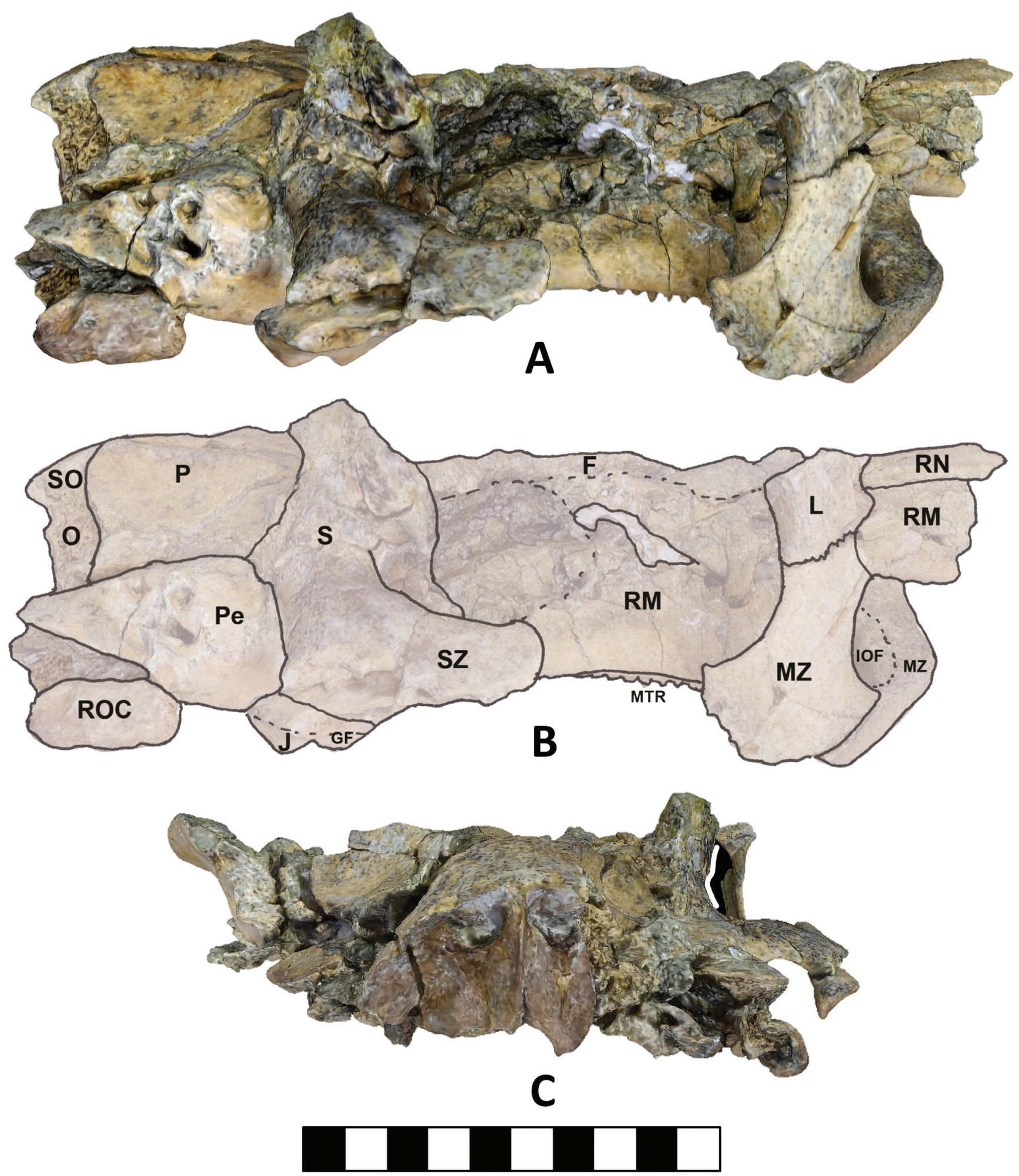

\section{$10 \mathrm{~cm}$}

Figure 6. SDSNH 50000. A \& B, lateral view; C, posterior view. In B, the boundaries of the bones are approximations, as the crushed condition of the skull prevented determining actual suture lines in many cases. Abbreviations: F, frontal; GF, glenoid fossa; J, jugal; L, lachrymal; MTR, maxillary tooth row; MZ, zygomatic process of maxilla; O, occipital; P, parietal; Pe, petrosal; RM, right maxilla; RN, right nasal; ROC, right occipital condyle; RPt, right petrosal; S, squamosal; SO, supraoccipital; SZ, zygomatic process of squamosal. Unlabeled areas are either fragments of bone which could not be allocated to a specific element, areas of crushed and comminuted bone, and matrix, or are gaps between bones where fragments have separated or are missing. 
White et al. - new Pleistocene Hydrochoerus from California

ous with the temporal crests marking the lateral edges of the posterior facing portion of the supraoccipital and occipital. The temporal crests appear to be continuous with the posterior edge of the paracondylar process as far as can be seen on the portion of the process preserved on the right side.

There is no indication of a supraoccipital-occipital suture; we interpret the suture to be completely ossified in contrast with the suture between the supraoccipital and the parietal which appears to be unfused. In posterior view, the dorsal margin of the occipital forms the nuchal crest, which is broadly rounded and evenly curved laterally and ventrally. Immediately below the nuchal crest, there is a small deep depression on either side of the vertical median crest of the supraoccipital. A second pair of shallower but larger depressions is present on the supraoccipital immediately above and lateral to the midline of the foramen magnum. The occipital is preserved, although the elongated paracondylar processes have been separated from the skull and cannot be reattached because of missing pieces. The right paracondylar process is more complete than the left and is relatively robust. We interpret the supraoccipital—paraoccipital suture as unfused. The dorsal margin of the foramen magnum is preserved, having a small, inverted $V$-shaped notch at its apex.

Lateral view: In lateral view (Fig. 6 A, B), the skull shows the crushed condition, with the right squamosal pushed up above the parietal table, and overriding parts of both the frontal and parietal. The zygomatic arch comprises the laterally and posteriorly directed zygomatic process of the maxilla, the jugal, and the laterally and anteriorly directed zygomatic process of the squamosal. The lateral zygomatic processes of both squamosals are preserved, while only the zygomatic process of the right maxilla is present. The zygomatic process of the left maxilla is missing, as is the left jugal (Fig. 6A). The anterior body of the right jugal remains attached to the posteriorly directed zygomatic process of the maxilla (not visible in Fig. 6 A, B). A small fragment of the posterior portion of the right jugal is preserved where it overlaps the anterior part of the zygomatic process of the squamosal, forming the mandibular fossa.

Ventral view: The ventral aspect of the skull (Fig. 5C, D) is more deformed than the dorsal, with the left side more distorted, fragmented, and more widely disarticulated than the right. The somewhat fractured palate is preserved with the individual fragments separated from each other by narrow bands of matrix. The entire palate, along with both tooth rows, is shifted to the right of the midline as defined by the basioccipital and basisphenoid, but is nearly complete. The right M2 and M3 are well preserved. The LM3 is represented by the posterior-most 4 prisms. Fragments of what is likely the LM1 and/or LM2 are present anterior to the remnants of the LM3 (Fig. 5C, D). The posterior portion of the palate has a rounded U-shaped posterior margin demarcating the nasal choanae. The pterygoid processes are relatively long and narrow. The suture between the palatal bone and the palatal portion of the maxillary bones is not visible. The area of the ventral exposure of the premaxillae and maxillae is largely missing and filled with matrix; the palatine fissure is not visible.

The basisphenoid is well preserved, as is the anterior half of the basioccipital. We are unable to determine whether the suture between the two bones is present and open, or if the bones were fused in life but are now broken. It is likely that, given the size of this individual, the suture was fused, as the basicranial sutures in modern capybara are all fused by 4 years of age, while many of the cranial sutures persist throughout the life of the individual (Ojasti 1973, 2011; Gorosabel et al. 2017). The paracondylar process is present on the right side but largely missing on the left, where only a small fragment of the dorsal-most part of the process remains.

The mandibular fossa for the articulation of the lower jaw is preserved on the right side. As in all hydrochoerines, the squamosal and the jugal participate in the formation of this fossa. The fossa is roofed dorsally by the zygomatic process

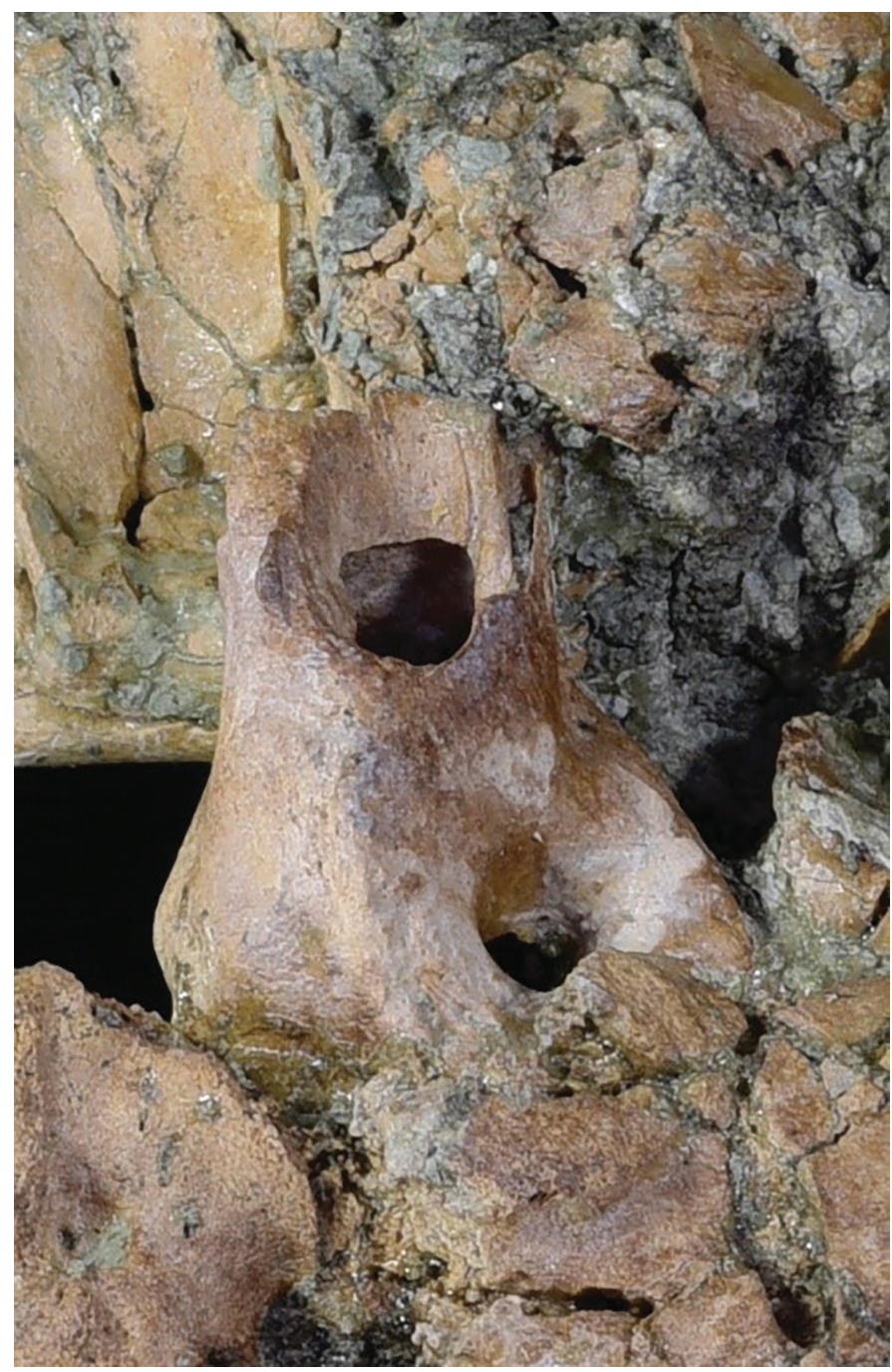

Figure 7. Hydrochoerus hesperotiganites SDSNH 50000 Right otic region of skull. Anterior toward top. 


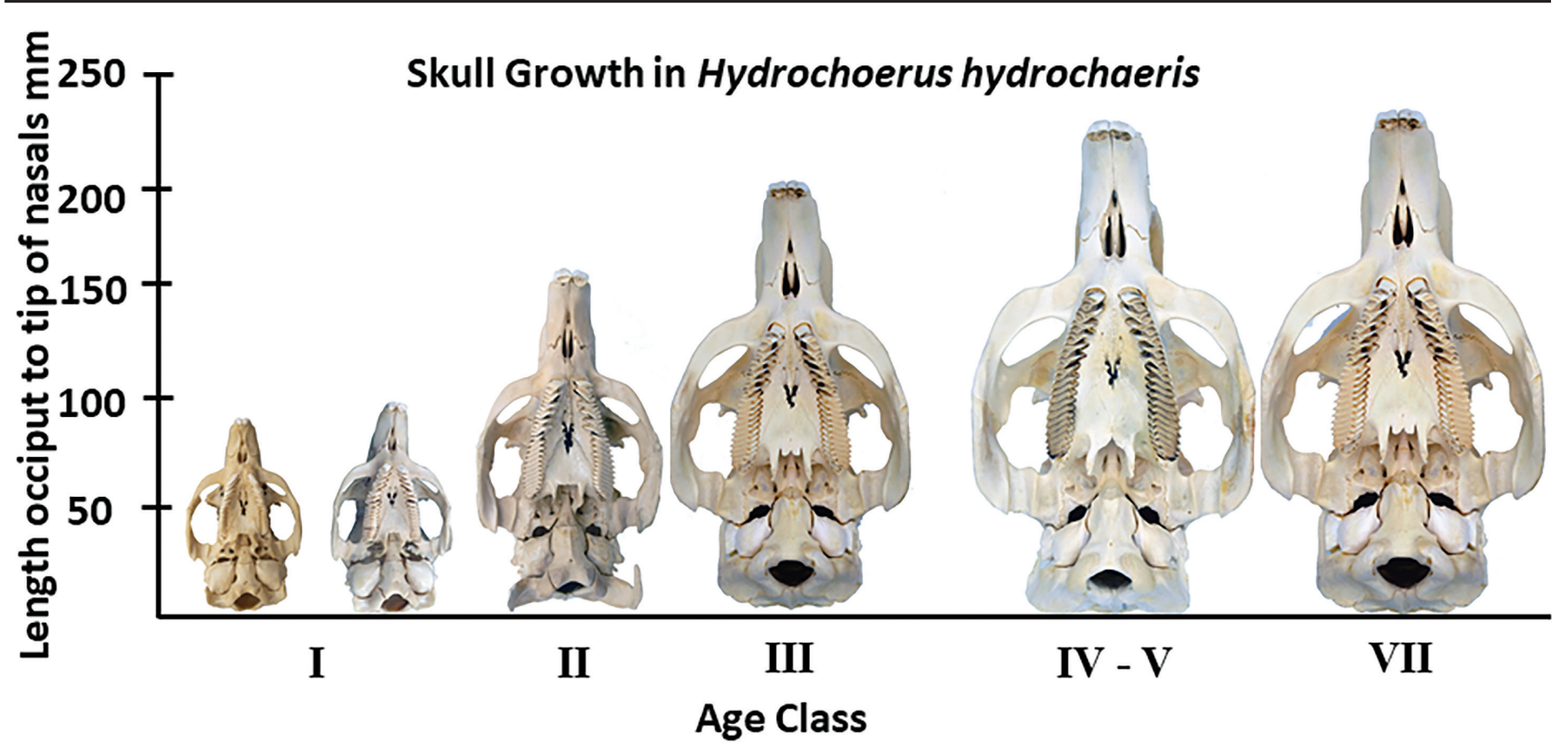

Figure 8. Skull growth in Hydrochoerus hydrochaeris. Specimens are, from left to right: MSCC 456, MSCC 457, MSCC 463, MSCC 461, MSCC 462, MSCC 460.

of the squamosal, which has a ridge produced ventrally forming the medial wall of the mandibular fossa. The posterior end of the jugal has a ridge produced ventrally which forms the lateral wall of the mandibular fossa. The two ridges serve to prevent any side-to-side movement of the mandible and limit its motion to the fore and aft movement characterizing propalinal mastication (Ahearn 1981). The otic region is variably preserved (Fig. 7). On the left side, the auditory bulla is complete, although fractured. The right bulla is lacking, exposing the petrosal, which is unbroken. Anteriorly, the lateral margin of the petrosal lies against the squamosal, reaching and overlapping the alisphenoid. Medial to the anterolateral-most part of the petrosal lies the rostral process of the malleus. There is a space between the alisphenoid and the petrosal between the two anterior processes of the petrosal, which forms the pyriform fenestra. Posterior and slightly medial to the pyriform fenestra is what we interpret to be either the oval window or the stapedius fossa or both. The anteromedial part of the petrosal reaches and overlaps the alisphenoid; in the extant species $H$. hydrochaeris the anterolateral process of the petrosal does not reach the alisphenoid because the rostral process of the malleus separates the two completely.

Table 2. Skull measurements (in $\mathrm{mm}$ ) of hydrochoerine specimens

\begin{tabular}{lccc}
\hline & $\begin{array}{c}\text { Hydrochoerus hesperotiganites } \\
\text { SDSNH MSCC 50000 }\end{array}$ & $\begin{array}{c}\text { Hydrochoerus hydrochaeris } \\
\text { MSCC 460 }\end{array}$ & $\begin{array}{c}\text { Neochoerus aesopi } \\
\text { MSCC 575 }\end{array}$ \\
\hline Length of Skull Nasal to Occipital & 250.3 & 230.2 & - \\
Length of R Nasal & 85.5 & 90.2 & - \\
Width of R Nasal & 33.5 & 27.3 & 121.2 \\
Length of Frontal, approximate & 102.1 & 91.6 & 65.8 \\
Length of Parietals & 53.9 & 59.0 & 34.1 \\
Posterior Width of Parietal Table & 45.6 & 26.0 & 108.6 \\
Anterior Width of Parietal Table & 76.4 & 76.8 & 28.1 \\
Length of Occipital & 18.5 & 21.3 & 73.2 \\
Width of Occipital, estimated & & 56.3 & 42.1
\end{tabular}

${ }^{1}$ Approximate measurement due to uncertainty of exact position of suture.

${ }^{2}$ Estimated using bilateral symmetry where one side is complete and the other incomplete. 


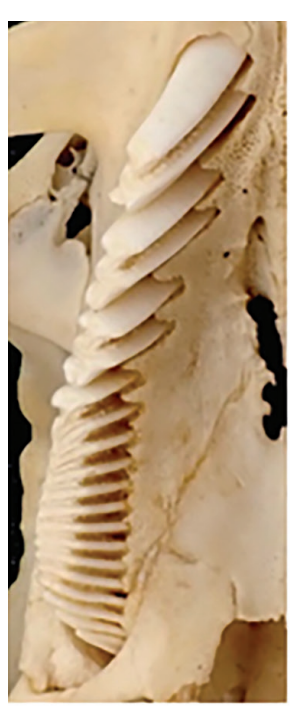

A

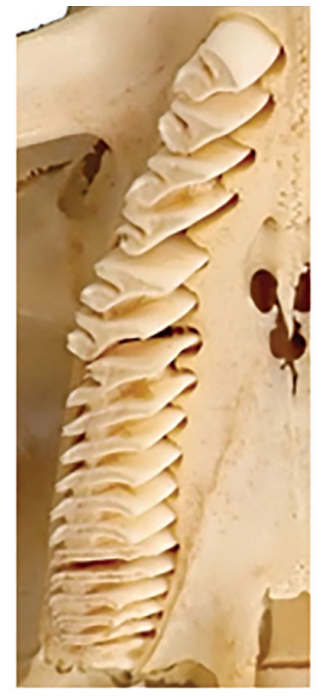

B

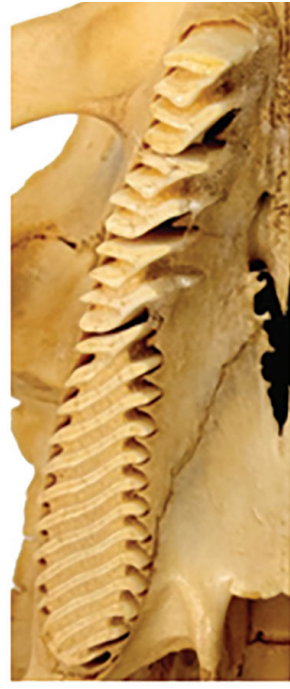

C

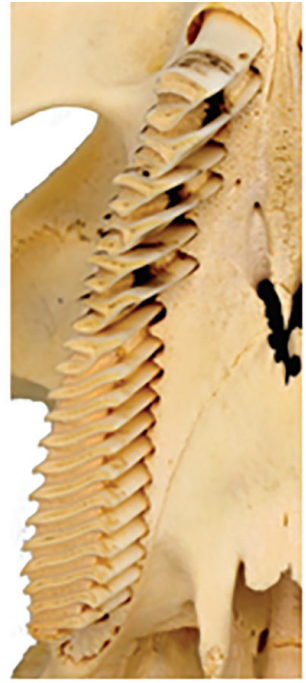

D

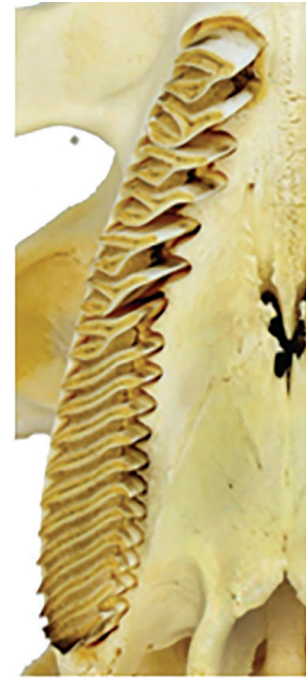

E

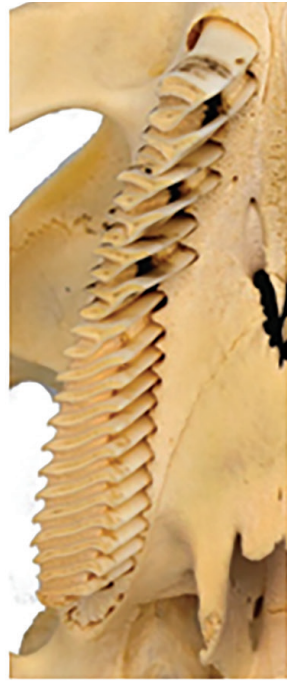

$\mathbf{F}$

Figure 9. Ontogenetic series of right mandibular tooth rows in Hydrochoerus hydrochaeris. A, Age Class I with no wear on anterior teeth (MSCC 456); B, Age Class I with wear on all teeth (MSCC 457); C, Age Class II (MSCC 463); D, Age Class III (MSCC 461); E, Age Class IV - V (MSCC 4620; F, Age Class VII (MSCC 460). Measurements of the upper third molar (M3) are provided in Table 5.

Mones (1974) described and beautifully illustrated the auditory region of the extant Hydrochoerus hydrochaeris. His drawings (Mones 1974:figs.3-22) of the auditory region of neonate, juvenile, and adult specimens match closely the specimens in our ontogenetic series (Fig. 8). Given that the auditory region is well preserved in SDSNH 50000, it is possible that there may be generically diagnostic characters present. We are unable to compare this with Neochoerus, since a comparably detailed description of the auditory region for Neochoerus has not been published.

Relatively few accurate measurements can be taken of SDSNH 50000 because of the crushed condition of the skull; those which can be either directly measured or approximated are provided in Table 2.

Dentition: SDSNH 50000 possesses three teeth that are well enough preserved to provide adequate description of the dentition. The RM2 and RM3 (Fig. 2) are preserved in their entirety. The RM3 has sunk into its alveolus due to compaction with its occlusal surface resting $-4 \mathrm{~mm}$ below the lateral rim of the maxilla. The incomplete left upper incisor (I1) is preserved with a partial premaxilla (Fig. 10B), which cannot be attached to the skull because of missing pieces.

The RM3 measures $49.6 \mathrm{~mm}$ in the anteroposterior length and $15.7 \mathrm{~mm}$ in maximum transverse width. There are 12 enamel prisms posterior to the BLFP, which has one enamel column on the lingual side of the tooth, and 2 columns on the buccal side separated by a distinct Hendedura Primera Externa (HPE, Fig. 2). The BLFP has been described as "V-shaped" (Ahearn 1981:64), or "Y-shaped" (Kerber and Ribeiro 2011:7); we follow Perez et al. (2017) and describe it as bi-lobed. While prism counts of the M3 have figured prominently in the literature and have been used as diagnostic at both the specific and generic level for hydrochoerids, the method of counting prisms and reporting those counts has varied considerably among the various authors, who were not always specific about the method used (Ahearn 1981; Mones 1991). For the purpose of this paper, we count, and report, the number of independent (free) enamel prisms (laminae) posterior to the BLFP as illustrated in Figure 2. The posterior prism sometimes has a tiny additional prism joined to it on the buccal side; we count them as two independent prisms following Mones (1991). Thus, our count is one less than reported by those authors who counted BLFP as a single prism (Ahearn 1981; Mones 1991). The RM3 of SDSNH 50000 has 12 enamel prisms posterior to the BLFP (Fig. 2).

M2 measures $12.6 \mathrm{~mm}$ anteroposteriorly and 10.0 $\mathrm{mm}$ in maximum transverse width at the second prism. The M1 and M2 are so nearly identical in Neochoerus and Hydrochoerus that they are not usually separated out in discussions of isolated teeth. In Hydrochoerus and Neochoerus, M1 and M2 are composed of two prisms, both in a V-shape open buccally and joined lingually. We follow Mones (1991) in counting the two lamina which make up each prism as a single prism, even where they lose their connection during wear. The re-entrant between the two lamina of each prism is termed the HPE (Hendedura Primera Externa) for the anterior prism I and the HSE (Hendadura Secundaria Externa) for the posterior Prism II (after Mones 1991, in turn based upon Rusconi (1939) and Kraglievich (1941) (Fig. 2). 
Table 3: Tooth measurements (in mm) of SDSNH 50000

Anterior-Posterior Length of RM2

12.60

Medial-Lateral Width of RM2

10.03

49.60

15.70

Medial-Lateral Width of RM3

13.90

Width of Upper L Incisor

9.72

In SDSNH 50000 the connections between the laminae making up each prism have been lost, likely due to wear, extending the HPE and HSE across the entire width of the tooth. Albright et al. (2019) figure a left M2 from an individual of uncertain age from the Cooper River in South Carolina that they refer to Neochoerus pinckneyi which has the laminae of both prisms joined lingually. Unfortunately, they do not provide measurements of this tooth. Mones (1991) provides drawings of M2 in Hydrochoerus hydrochaeris at birth, 4 weeks, 6 weeks, and adult; all have the laminae of both prisms joined lingually. The incomplete left I1 (Fig. 10B) has a curvilinear length of $51.00 \mathrm{~mm}$ (as measured along the anterior enamel margin), a width of $13.90 \mathrm{~mm}$, and a depth of $9.72 \mathrm{~mm}$ distally, with a width of $14.24 \mathrm{~mm}$ and a depth of 9.77 mm proximally. It has a wide, shallow groove on the anterior enamel covered surface. Visible in incident light are fine longitudinal striations, both within the groove and lateral to it; no sharply marked longitudinal ridges are present. The root end of the tooth has a damaged but open pulp cavity. When fitting the partial tooth to the isolated ventral and dorsal portions of the left premaxilla, it is clear that the preserved portion of the incisor was unerupted and entirely within the incisor alveolus. Dental measurements are provided in Table 3.

\section{TAXONOMIC ASSIGNMENT}

Identifying North American Pleistocene capybara fossils has long been a contentious undertaking (Ahearn 1981; Mones 1991; Vucetich et al. 2015; Carranza-Castañeda 2016). In the past, taxonomic assessment has relied primarily on three morphological features, one on the mandible, one on the skull, and one on the upper and lower incisors. The masseteric ridge of the mandible has been used to separate Neochoerus (originally including $N$. dichroplax, now assigned to the genus Phugatherium) from Hydrochoerus. In Neochoerus (less $N$. dichroplax), the masseteric ridge begins lateral to the middle of the last prism (PIII) of p4, according to Ahearn (1981), while in Hydrochoerus, the masseteric ridge begins lateral to the middle prism (PII). Since SDSNH 50000 lacks the lower jaws, it cannot be allocated to either genus based on characters of the lower jaw.
The upper and lower incisors of both genera have a wide anteromedial longitudinal groove on the enamel surface of the tooth. Hydrochoerus was diagnosed by Ahearn (1981) as grooved but lacking ridging on the enamel surface, while Neochoerus has both the groove and ridged enamel (Fig. 10). Based on our examination of six extant Hydrochoerus hydrochaeris, this character needs slight revision. Careful examination of those six specimens in incident light reveals that faint longitudinal striations are visible both within the groove and to the lateral and medial side of the groove (Fig. 10C). We propose changing the character state seen in Neochoerus to "pronounced ridging" of the enamel. SDSNH 50000 is grooved, and lacks the pronounced ridging seen in Neochoerus, but does have faint striations visible, as in Hydrochoerus (Fig. 9C). Thus, SDSNH 50000 is referrable to Hydrochoerus based in part on this character of the upper incisor.

The character most often used to allocate specimens to hydrochoerine genera has been the M3, specifically the number of enamel prisms present. Dental characters have been discounted by some workers who note that size and occlusal pattern change markedly through ontogeny (Prado et al. 1998; Vucetich et al. 2005). Additionally, confusion has been caused by the different methods employed to count the number of prisms as noted above. Ahearn (1981:62) characterizes the genus Neochoerus as having an M3 "...composed of an anterior Prism with a V-shaped cross-section followed by 13 to 16 separate laminae." following the BLFP, while Hydrochoerus has 11 or 12 separate lamina. According to Ahearn (1981:62), Neochoerus pinckneyi has an M3 "...composed of seventeen prisms (laminae)". We interpret this to mean that it has a BLFP and 16 independent laminae.

Table 4 presents descriptions of M3 as used by Ahearn (1981), Mones (1991) and Vucetich et al. (2015) to characterize the genera and species of North American hydrochoerines. We interpret the terminology of both Ahearn (1981) and Mones (1991) based on their written descriptions as well as the illustrations they provided. It should be noted that the low prism count for Neochoerus reported by Ahearn (1981) and Mones (1991) is due to the inclusion of South American species of Neochoerus, particularly $N$. tarijensis and $N$ sulcidens. No North American specimens of Neochoerus have been reported with fewer than 15 post-BLFP prisms. The Central American skulls of Neochoerus examined by us directly or in photographic images also have 15 or more post-BLFP prisms. A more complete review of the South American species is needed to determine their status. We here consider 15 or more post-BLFP prisms as diagnostic for North American species of Neochoerus.

Several authors have remarked that tooth morphology, including size, prism counts, and occlusal pattern, vary 
Table 4. Description of $M_{3}$ in hydrochoerines by previous authors and as used in this study.

\begin{tabular}{|c|c|c|c|c|}
\hline Taxon & Ahearn 1981 & Mones 1991 & Vucetich 2015 & This study \\
\hline Hydrochoerus & $\mathrm{BLFP}+11-12$ & $\mathrm{BLFP}+9-13$ & - & BLFP + $10-13$ \\
\hline H. holmesi & BLFP + 11-12 & - & - & - \\
\hline Neochoerus & $\mathrm{BLFP}+13-16$ & $\mathrm{BLFP}+12-16$ & - & BLFP + 15- 161 \\
\hline N. dichroplax & $\mathrm{BLFP}+14-15$ & $\mathrm{BLFP}+15$ & - & - \\
\hline$N$. aesopi & - & $\mathrm{BLFP}+15-16$ & - & $\mathrm{BLFP}+15-16$ \\
\hline N. tarijensis2 & - & $\mathrm{BLFP}+13-14$ & - & - \\
\hline N. sulcidens2 & - & $\mathrm{BLFP}+12-13$ & - & - \\
\hline Phugatherium & - & - & $\mathrm{BLFP}+14-18$ & $\mathrm{BLFP}+14-18$ \\
\hline P. cataclisticum 2 & - & - & $\mathrm{BLFP}+16-18$ & - \\
\hline P. dichroplax & - & - & - & $\mathrm{BLFP}+15$ \\
\hline
\end{tabular}

${ }^{1}$ Excludes South American species

${ }^{2}$ Indicates South American species

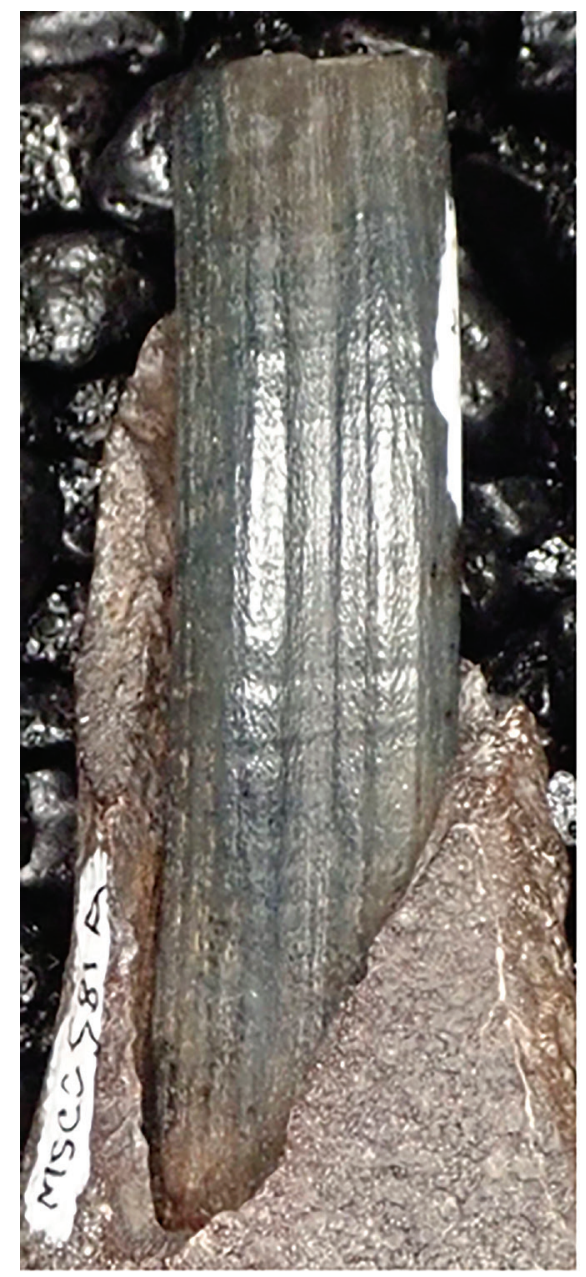

A

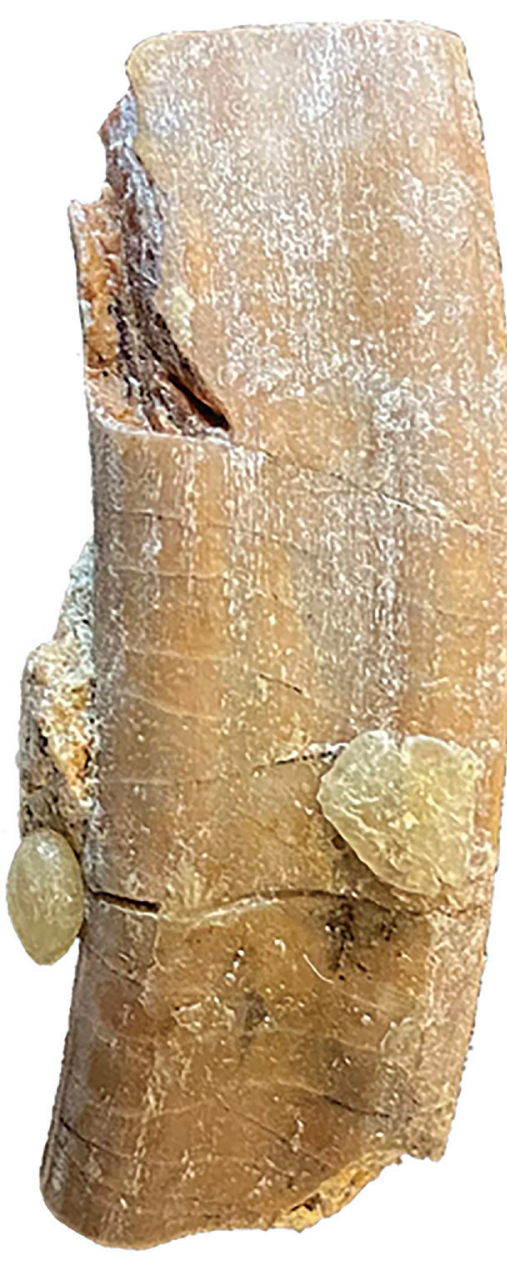

B

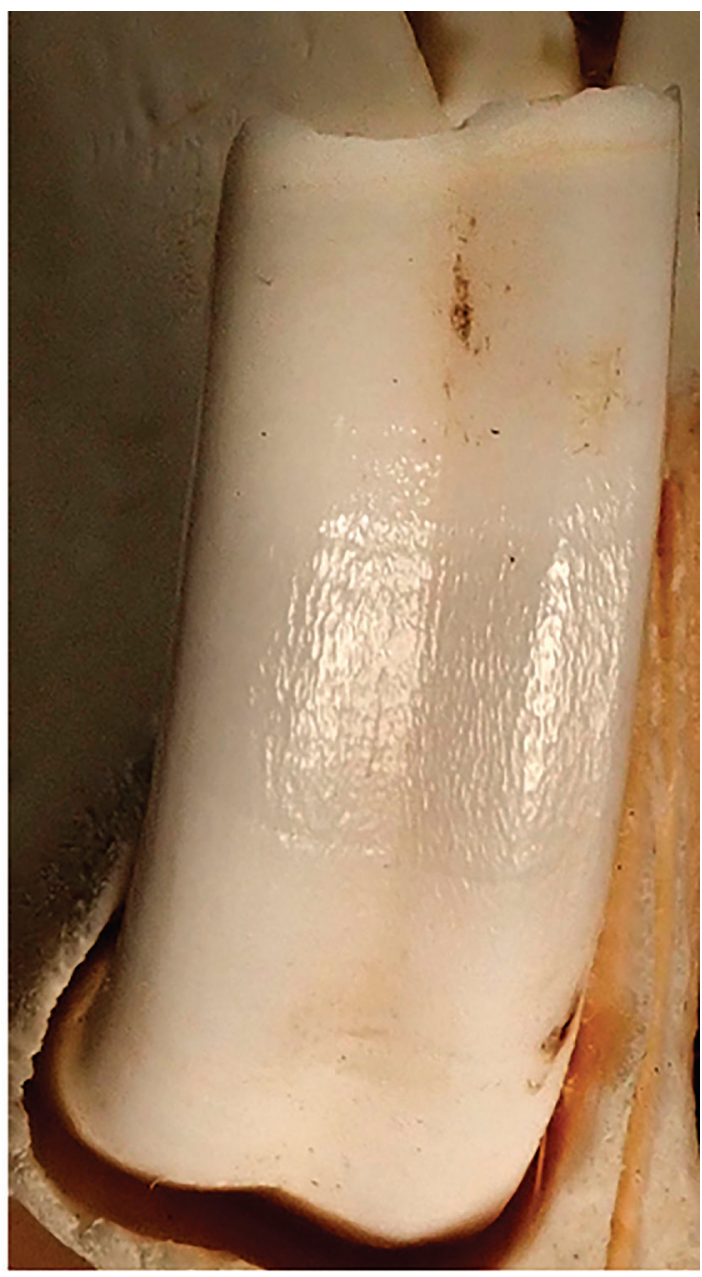

C

Figure 10. Anterior enamel surface of incisors. A, Neochoerus aesopi, MSCC 581, Florida; B, Hydrochoerus hesperotiganites, SDSNH 50000, California; ,. Hydrochoerus hydrochaeris, MSCC 461, zoo specimen. 
Table 5. Ontogenetic series of Hydrochoerus hydrochaeris M3s.

Specimen Number Age Class Calendar Age Post- BLFP Independent Prisms Length of M3 (mm) Width of M3 (mm)

$\begin{array}{lccccc}\text { MSCC 456 } & \text { I } & 0-4 \text { months } & 13 & 13.5 & 3.5 \\ \text { MSCC 457 } & \text { I } & 0-4 \text { months } & 12 & 15.9 & 5.6 \\ \text { MSCC 463 } & \text { II } & 4-12 \text { months } & 11 & 30.4 & 12.0 \\ \text { MSCC 461 } & \text { III } & 1-1.5 \text { years } & 12 & 35.1 & 12.9 \\ \text { MSCC 462 } & \text { IV-V } & 1.5-2 \text { years } & 11 & 43.3 & 15.8 \\ \text { MSCC 460 } & \text { VII } & 4 \text { years and up } & 12 & 48.2 & 17.2\end{array}$

Table 6. M3 prism counts in Hydrochoerus hydrochaeris, data from Mones (1991); N = 57.

\begin{tabular}{cccc}
\hline Number of prisms & Number of Post-BLFP Prisms & Count in sample & \% of sample \\
\hline 11 & 10 & 1 & 1.8 \\
12 & 11 & 20 & 34.9 \\
13 & 12 & 34 & 59.4 \\
14 & 13 & 2 & 3.7 \\
\hline
\end{tabular}

ontogenetically, and thus should not be given much taxonomic weight (Prado et al. 1998; Vucetich et al. 2005). Mones (1991:fig. 7) illustrated the ontogenetic changes in M3 of extant Hydrochoerus hydrochaeris.

In order to further evaluate the usefulness of prism counts as a taxonomic character, we examined an ontogenetic series of six modern skulls of Hydrochoerus hydrochaeris (Figs. 8, 9), ranging in age from about 4 months (Age Class I) to $4+$ years
(Age Class VII) based on the scheme of Ojasti $(1973,2011)$ as utilized by Gorosabel et al. (2017). Counts of the independent prisms posterior to the BLFP and the length and width of the M3 are presented in Table 5. Figure 9 shows enlarged views of the individual tooth rows; Figure 8 shows the 6 skulls to scale to illustrate skull growth. As can be seen from this relatively small sample, the number of independent prisms ranges from 11 to 13 but is not correlated with

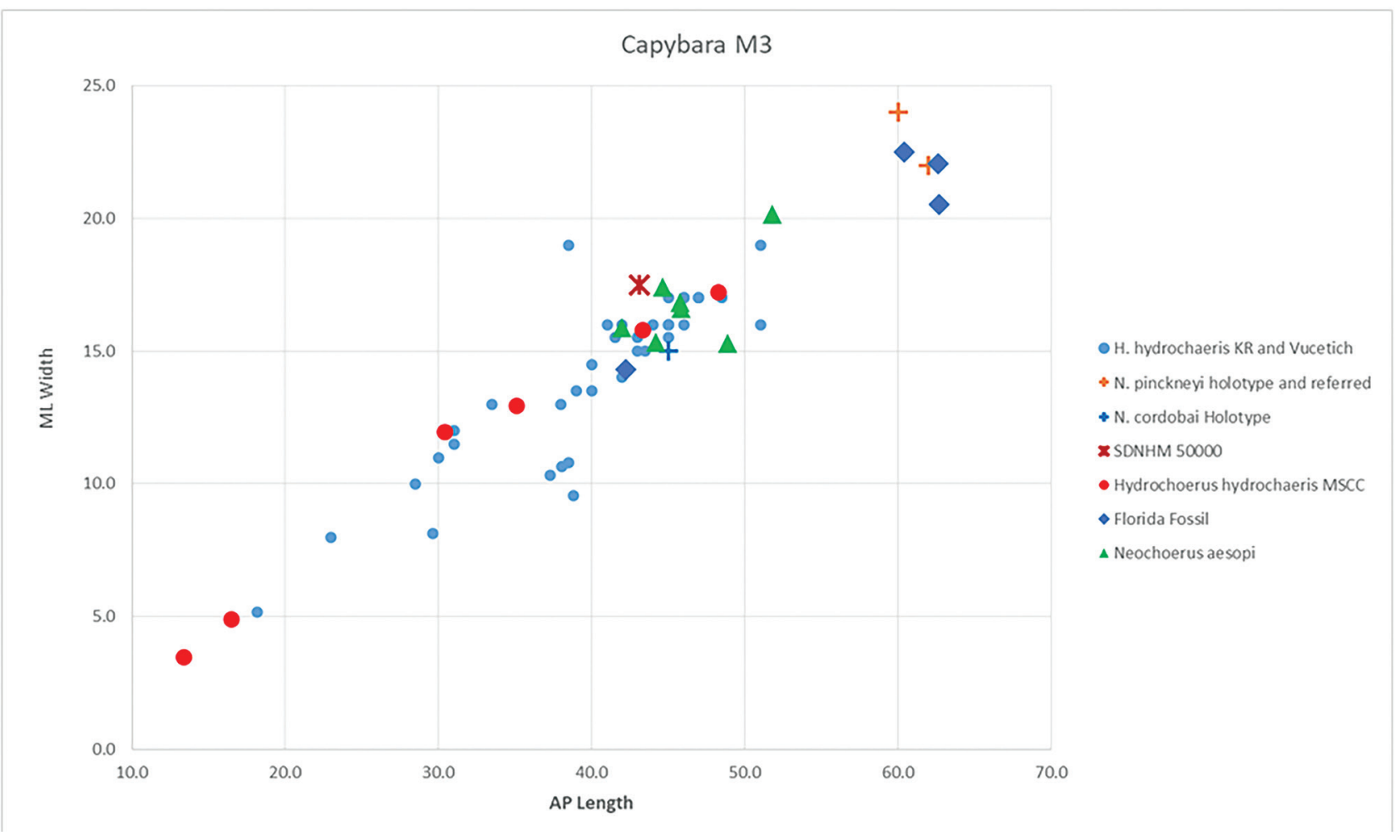

Figure 11. Bivariate plot of $M_{3}$ measurements of capybaras. 
White et al. - new Pleistocene Hydrochoerus from California

ontogeny. Mones (1991) reported on a sample of 57 M3s of Hydrochoerus hydrochaeris from Uruguay. Table 6 summarizes those counts and their percentage in the entire sample. Additional data on the M3 of extant Hydrochoerus hydrochaeris were published by Hooijer (1959) who measured a series of 20 capybara skulls in the Leiden Museum, recording the length of the M3 and the basilar length of the skull. We have plotted his data, with the data from our 6 specimens, in Figure 12. It is clear from this plot that the length of M3 increases throughout ontogeny.

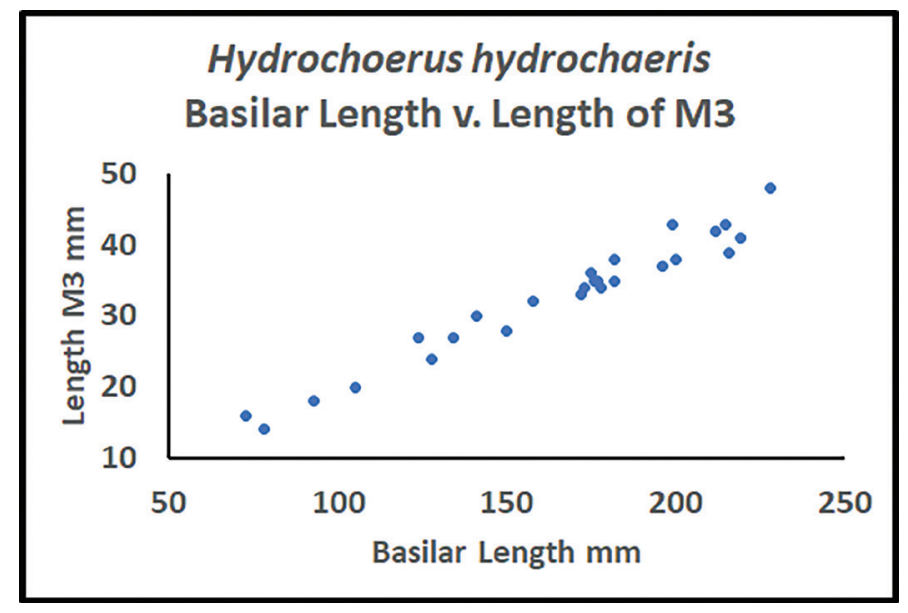

Figure 12. Bivariate plot of the length of $M_{3}$ plotted against the basilar length of the skull. Data from a sample of extant $\mathrm{H}$. hydrochaeris in Hooijer (1959) and from our sample of extant $H$. hydrochaeris (Tab. 5). $\mathrm{N}=26$.

Gorosabel et al. (2017) examined 250 skulls collected in northern Argentina, stating that the skulls corresponding to different age categories exhibited the same number of prisms. It is unclear whether they intended to indicate that the entire sample has the same number of prisms, or that each age category has the same range of plate counts. However, either interpretation suggests that variation in prism count in the teeth of extant Hydrochoerus hydrochaeris is unrelated to ontogenetic age. Aeschbach et al. (2016) examined the growth of the cheek teeth in their samples of $117 \mathrm{H}$. hydrochaeris and $H$. isthmus and concluded that the number of prisms did not change through post-natal ontogeny. These data all indicate that the changes in occlusal pattern occur within the first 3 to 4 months; and that after that time, the occlusal pattern, particularly the prism count, is remarkably stable.

Other characters have been utilized to differentiate Hydrochoerus from Neochoerus. We note here that all specimens we were able to find in the literature that have been referred to Neochoerus pinckneyi are exceedingly large. Figure 11 presents a bivariate plot of the length and width of the upper third molar (M3) based on measurements in Kerber and Ribiero (2011), Vucetich et al. (2005), CarranzaCastaneda and Miller (1988), Hay (1923) and our own measurements. It is curious that no smaller specimens have been assigned to that taxon. In contrast, smaller specimens have been assigned to both Neochoerus aesopi and Hydrochoerus holmesi. Ahearn (1981) considered H. holmesi to be a nomen dubium but noted that the ridged incisor of the type might indicate a small or juvenile Neochoerus (in which she also included $N$. dichroplax). Mones (1991) included both $H$. holmesi and $N$. pinckneyi in Neochoerus aesopi. Baskin et al. (2020) considered H. holmesi to be a junior synonym of $N$. aesopi. These authors recognized just one species of Neochoerus from the late Blancan through the late Rancholabrean of North America, Neochoerus aesopi. Given the existence of juvenile specimens of both Neochoerus and Hydrochoerus, it seems unlikely that only fully adult Neochoerus pinckneyi have been found. We are not convinced by the arguments of Mones (1991), accepted by most recent authors, that all of the specimens of $N$. pinckneyi referred by him to $N$. aesopi are correctly allocated, particularly those dating to the Blancan NALMA. Given the significant range in size of the three species allocated to Hydrochoerus, the most parsimonious interpretation, and the one followed here, is that the specimens identified as $H$. holmesi in the bivariate plot of Ahearn (1981), and those described by others as $N$. aesopi (Baskin et al. 2020; Carbot-Chanona et al. 2020) are simply younger conspecifics of the large, presumably fully adult individuals identified as Neochoerus pinckneyi. This confusion is exacerbated by the difficulty in aging capybara specimens independent of tooth size. Nevertheless, we advocate for a more thorough study of this problem that includes Florida Blancan and Irvingtonian samples.

Another potentially diagnostic character was first described by Simpson (1930:9) involving the skull roof.

"It is the skull roof that most obviously distinguishes fossil and recent animals. The frontal region on the fossil is very broad and nearly flat. The sagittal crests on the parietals narrow very rapidly: at the postorbital processes they are nearly twice as wide as in Hydrochoerus, while at the contact with the supraoccipital (or interparietal?) they are of almost the exact same width as in the latter. The roof of the parietals is not arched and does not curve downward posteriorly but continues the plane of the frontals and rises to a point at the supraoccipital suture. The interparietal part of the supraoccipital is relatively longer in the fossil, and the occiput relatively higher."

Mones (1991:39, translation by RSW) included characters of the skull roof in his generic diagnoses of Hydrochoerus and Neochoerus:

[Hydrochoerus with] "... face relatively shorter than Neochoerus, with the skull roof proportionally shorter at the level of the frontals and nasals, and slightly 
descending towards the occiput; thinner anteorbital bar and less robust lacrimal; supraoccipital narrower and less excavated.

[Neochoerus differs] “... from Hydrochoerus in: size one third to two times larger; proportionally longer face; anterior portion of the zygomatic arch more rounded and directed backwards, less transverse; more robust anteorbital bar and lacrimal; skull roof very broad, proportionally wider through the nasals and frontals, with these proportionally shorter and the parietals longer, occiput less convergent dorsally, supraoccipital wider and relatively more excavated; ...” (Mones 1991:49)

Interpreting this character complex is somewhat subjective in SDSNH 50000 since the skull has been extensively crushed dorso-ventrally. In addition, Mones (1991) included "Neochoerus dichroplax" in his diagnosis of the genus in which he discussed only dental characters, so we are unable to determine how the rest of his diagnosis for the genus would be affected by the reallocation of $N$. dichroplax to the genus Phugatherium (Vucetich et al. 2015). SDSNH 50000 is somewhat larger than the largest of the modern Hydrochoerus hydrochaeris specimens available to us (MSCC 460). The skull length, measured from the posterior edge of the occipital to the anterior end of the nasals is $9 \%$ larger than MSCC $460(250.3 \mathrm{~mm}$, versus $230.2 \mathrm{~mm}$ ). Other measurements vary from smaller to larger in SDSNH 50000 than MSCC 460 (Table 2), but how much of this is due to the distortion in the fossil is unclear. SDSNH 50000 is clearly somewhat larger than our largest modern specimen, MSCC 460, but nowhere near the 33-50\% larger condition described by Mones (1991) for Neochoerus. The parietals and frontals appear broader in SDSNH 50000 than in modern Hydrochoerus. In addition, the supraoccipital of SDSNH 50000 is broader and gently rounded laterally and ventrally, as opposed to MSCC 460, where the supraoccipital is higher, less broad and has a straighter slope laterally. Our ontogenetic sample of modern $H$. hydrochaeris shows that the supraoccipital does not unite with the occipitals until Age Class IV where it is partly, but not completely, fused. In Age Class VII no suture is visible.

Since we cannot reliably separate the effect of distortion and the difference in size in skull roof proportions, we are not confident that this character complex is well-enough defined to be considered in our taxonomic assignment.

Considering all the above, SDSNH 50000 can confidently be allocated to Hydrochoerus, based on the morphology of M3 and I1 as described. The fact that the skull is somewhat larger, and the likelihood that the skull roof is relatively broader in SDSNH 50000 than in living $H$. hydrochaeris indicates its specific distinctiveness from the extant $H$. hydrochaeris, as does the more robust zygomatic process of the maxilla and descending zygomatic process of the lacrimal. Characteristics of the otic region are also different from those in extant Hydrochoerus, although the true taxonomic significance of these differences cannot be meaningfully evaluated until descriptions of this area in other hydrochoerines are available. Although we cannot adequately quantify the difference in the breadth of the skull because it is crushed and distorted, the other differences are clearly defined and justify the establishment of the new species Hydrochoerus hesperotiganites.

\section{BIOGEOGRAPHY}

Capybaras (Caviidae: Hydrochoerinae) and the porcupine Erethizon (Erethizontidae) are the only two groups of South American caviomorph rodents that reached temperate North America in the late Pliocene to early Pleistocene (late Blancan and early Irvingtonian) phase of the Great American Biotic Interchange (GABI) (Frazier 1981; Morgan 2005, 2008; Woodburne 2010; Vucetich et al. 2015). This later phase of the GABI began in the early Pliocene about 5 Ma with the final connection of North America and South America at the Isthmus of Panama (O'Dea et al. 2016). During an earlier phase of the GABI in the late Miocene (early Hemphillian NALMA, $\sim 9 \mathrm{Ma}$ ), two genera of ground sloths in the families Megalonychidae and Mylodontidae apparently reached North America by overwater dispersal from South America (Morgan 2005; 2008). Although our paper describing a new species of the extant genus Hydrochoerus from the late Pleistocene is not the appropriate place for a detailed discussion of the biogeography and systematics of capybaras associated with the late Pliocene and early Pleistocene phase of the GABI, it is nevertheless important to establish the evolutionary history of Hydrochoerus and other hydrochoerines in North America.

Three genera of capybaras, the extinct Neochoerus and Phugatherium and the extant Hydrochoerus, have been reported from the North American fossil record (Ahearn 1981; Mones 1991; Morgan 2005, 2008; Vucetich et al. 2015). Phugatherium was named from the Pliocene of Argentina and is represented in North America by the species P. dichroplax (Vucetich et al., 2015), originally described as Neochoerus dichroplax from three late Blancan faunas in the southern USA, 111 Ranch (= Dry Mountain) in Arizona (type locality) and two sites in southern Florida (Ahearn and Lance 1980). Morgan and Hulbert (1995) and Hulbert (2010) reported several additional late Blancan records of $N$. (= P.) dichroplax from Florida. The earliest well-dated capybara from North America is $N$. cordobai from the early Blancan $(-3.6 \mathrm{Ma})$ of central México (Carranza-Castañeda and Miller 1988). Although Vucetich 
White et al. - new Pleistocene Hydrochoerus from California

et al. (2015) synonymized $N$. cordobai with the late Blancan ( -2.5-2.7 Ma) N. dichroplax from the southern USA, Carranza-Castañeda (2016) recognized N. cordobai as a valid species of Neochoerus and also described a new species $N$. occidentalis from several late Blancan and early Irvingtonian faunas in México. Neochoerus (not including Phugatherium but including most previous North American records of Hydrochoerus—see below) first appeared in either the early Blancan of México or the late Blancan of Florida and South Carolina (Ahearn 1981; Morgan 2005; Vucetich et al. 2015; Carranza-Castañeda 2016; Albright et al. 2019). Several of these North American Blancan capybaras appear to be older than the oldest records of Neochoerus from South America (Vucetich et al. 2015). That begs the question-did Neochoerus evolve in South America and disperse to North America in the Pliocene as a participant in the GABI, or did Neochoerus evolve in North America from Phugatherium dichroplax or a species closely related to $N$. cordobai? An answer to this question will require more detailed systematic studies of North American Blancan capybaras, which is beyond the scope of this paper.

More relevant to our current study is the status of fossil capybaras from North America previously referred to the living genus Hydrochoerus. Simpson (1928) described an extinct species of Hydrochoerus, $H$. holmesi, from the late Pleistocene (Rancholabrean) Sabertooth Cave in Florida. Many other Florida fossil capybaras have since been referred to $H$. holmesi, including specimens as old as late Blancan (Ahearn 1981; Morgan 2005). However, the taxonomic studies we follow here (e.g., Mones 1991; Baskin et al. 2020) transferred $H$. holmesi to Neochoerus and have also synonymized this species with $N$. aesopi, in which they also included $N$. pinckneyi. Although these authors proposed that $N$. aesopi occurred over a time period of nearly 2 million years, from the late Blancan to the late Rancholabrean, it is worth noting that few Rancholabrean species of North American mammals have chronologic ranges that extend back into the Blancan (Kurtén and Anderson, 1980). Furthermore, Vucetich et al. (2015:325) stated “...extinct species [of capybaras] had short stratigraphic ranges (partly because of their physiological requirements) and relatively wide geographic ranges, rendering them useful as biostratigraphic tools...". Most late Blancan and Irvingtonian samples of Neochoerus from the southeastern United States, in particular Florida, have not been studied in detail and may represent a species of Neochoerus distinct from $N$. aesopi (= $N$. pinckneyi $=H$. holmesi .

In summary, it appears that all previous fossil records of capybaras from North America represent one of two extinct genera, Neochoerus or Phugatherium. These records span the time period from the late Pliocene $(-3.6 \mathrm{Ma})$ of central México to the late Pleistocene of the southeastern United
States and Central America, with Phugatherium known only from the Blancan and Neochoerus occurring in the Blancan, Irvingtonian and Rancholabrean. Following the current taxonomy, with referral of Hydrochoerus holmesi to Neochoerus aesopi (Mones 1991; Baskin et al. 2020), none of the previously described North American capybaras belong to the extant genus Hydrochoerus. Consequently, the new species described here, $H$. hesperotiganites, from the Rancholabrean of southern California appears to be the only valid fossil record of Hydrochoerus from North America, causing us to rethink the biogeography of this genus. With the northern-most range extension of the living capybara $H$. isthmius in eastern Panama, there appears to be no record of Hydrochoerus, living or fossil, between Panama and southern California.

Determining which species of capybara crossed the Panamanian Land Bridge, and when, as well as what route they took in their dispersal northwards into North America would naturally begin, of course, with Central America and southern México. However, the fossil record of capybaras is extremely limited for Central America, with just five records (one unpublished), all probably, but not certainly, of Pleistocene age. Importantly, all are identified as Neochoerus rather than Hydrochoerus. The unpublished record is from Guatemala, in the American Museum of Natural History (FM 94034; RSW notes), the other in the Paleontological Museum in Estanzuela, Guatemala (PV-H-45; McDonald and Davila A 2017; H.G. McDonald, personal communication). Judging from the available photographs, both specimens appear to be Neochoerus, as they have M3s with 15 independent prisms following the BLFP. The published records include one each in San Salvador (Webb and Perrigo 1984), Nicaragua (Leidy 1887; Lucas et al. 2008), Honduras (Ahearn 1981; Webb and Perrigo 1984) and Guatemala (Lucas et al. 2021; McDonald and Davila A 2017; H.G. McDonald, personal communication). All four were identified as Neochoerus and dated as late Pleistocene. McDonald and Davila A (2010) map the occurrence of Mammuthus columbi in Central America; all known occurrences are confined to the Pacific lowlands of El Salvador, Honduras, Nicaragua, and Costa Rica. This suggests that the corridor for southward dispersal (and presumably northward as well) was along the Pacific Coast. Alternate explanations could be that there has been less paleontological exploration along the Atlantic coast and the interior highlands; or that an Atlantic dispersal corridor lies east of the present shoreline and was submerged by rising sea levels after the last glacial high sea level. Certainly, intensive exploration of the interior and the Atlantic coast areas is desirable.

The only record of Rancholabrean capybaras from southern México is that reported by Carbot-Chanona et al. (2020) from Chiapas and discussed below. Given the 
paucity of records of capybaras in Central America and southern México, we will confine our analysis and speculations primarily to central and northern México and to the southwestern United States.

Late Pleistocene (Rancholabrean) records of capybaras from central and northern México include abundant material from Lake Chapala, Jalisco, which has been referred to Hydrochoerus magnus (Peters 1951), Hydrochoerus (Alvarez 1971), Neochoerus (Carranza-Castañeda and Miller 1988), Neochoerus ?pinckneyi (Rufolo 1998), Neochoerus aesopi (Mones 1991), Neochoerus aesopi (Lucas 2008) and Hydrochoerus sp. (Carranza-

Castañeda 2016). Carbot-Chanona et al. (2020) after a careful review of the material, rejected the presence of Hydrochoerus in the Lake Chapala fauna, assigning the Lake Chapala capybara to Neochoerus aesopi.

Fossil capybara has been reported from the Rancholabrean site of Térapa, Sonora, in the Rio Moctezuma drainage. Initially referred to Hydrochoerus sp. by Mead et al. (2006) and later as Hydrochoeridae indeterminate (Nunez et al. 2010), the Térapa material was referred to Neochoerus aesopi by Carbot-Chanona et al. (2020), even though they did not examine the fossils and no illustrations have been published. These fossils are currently under study by the authors. A fossil capybara from Media Luna lagoon, San Luis Potosi, described by Hernandez-Junquera (1977) as Hydrochoerus sp. was, as Carbot-Chanona et al. (2020) noted, never deposited in a museum and is now presumed lost. While they refer that missing material to Neochoerus aesopi, we prefer to leave it as Hydrochoerinae indeterminate. Further south in México, fossil capybaras have been reported from the late Pleistocene site of Valsequillo, Puebla, as Hydrochoerus by Pichardo (1997), and as Neochoerus sp. by Perez-Crespo et al. (2014, 2017). CarbotChanona et al. (2020) examined some of this material (an incomplete skull) and documented the morphological features which allow it to be assigned to Neochoerus aesopi. Carbot-Chanona et al. (2020) describe significant well preserved capybara material from the late Pleistocene (Rancholabrean) Los Mangos locality in Chiapas, allocating it to Neochoerus aesopi. Hydrochoerus is represented in the fossil record of South America (Mones 1991) but not in Central America; this may be the result of the paucity of well investigated sites in Central America.

We are thus left with no confirmed recent or late Pleistocene record of Hydrochoerus between eastern Panama and the San Luis Rey River in southern California, a distance of about $6,000 \mathrm{~km}$ (3,730 miles). The previous northwestern-most record for a Pleistocene capybara is the latest Blancan or early Irvingtonian record of Neochoerus occidentalis from El Golfo, Sonora (Croxen et al. 2007; Carranza- Castañeda 2016) and the late Blancan record of Phugatherium dichroplax from 111 Ranch in Arizona
(Ahearn and Lance 1980; Galusha et al. 1984; Tomida 1987). Capybaras appear in the Rancholabrean of northern Sonora at Térapa, 180 kilometers (112 miles) south of the México / USA border. There is no Rancholabrean record of any capybara in Arizona, New Mexico, or in western Texas. Ceballos et al. (2010) defined seven corridors through which mammals moved in and out of México to establish their present distribution. Two of those routes, the Sonora - Central American Lowlands along the Pacific Coast of México and the Tamaulipas - Central America Gulf Lowlands along the Gulf of México, are relevant to our discussion of capybara dispersal into northern México and the United States.

Florida has the most diverse Plio-Pleistocene Interchange mammalian fauna in temperate North America with more than ten species (Morgan 2005), including two genera of capybaras, Phugatherium and Neochoerus (Ahearn and Lance 1980; Vucetich et al. 2015). Mammals that participated in the Plio-Pleistocene phase of the GABI first appeared in Florida in the early Pleistocene (late Blancan; about 2.5 Ma), including Phugatherium dichroplax. Webb (1974, 1978) proposed that the Florida Interchange fauna used a dispersal route he called the 'Gulf Coast Savanna Corridor' (GCSC), equivalent to and an extension of the Tamaulipas - Central America Gulf Lowlands corridor of Ceballos et al. (2010:fig. 6, corridor 6) and corresponding to the coastal plain of the Gulf of México from southern México to Florida. A northern extension of this corridor existed along the southeastern Atlantic Coastal Plain, allowing the northward dispersal of several members of the GABI fauna into Georgia and South Carolina, including the capybara Neochoerus aesopi (Sanders 2002; Albright et al. 2019). Morgan and Emslie (2010) proposed that the GCSC was active throughout the Pleistocene, serving as a pathway for certain tropical species of mammals, as well as birds, to disperse from Central America around the Gulf of México to tropical/subtropical habitats in the Florida peninsula. The Gulf Coastal Plain of Texas was part of the GCSC, supporting a diverse GABI mammal fauna in the late Pleistocene, including $N$. aesopi (Baskin and Thomas 2007; Baskin et al. 2020).

Confining our considerations to northern México and the southwestern United States, we can envision several potential routes for the dispersal of capybaras from central and southern México. These routes fall within the northern-most portions of the western-most corridor defined by Ceballos et al. (2010:fig. 6, corridor 7) for México: the Sonora - Central American Lowlands along the Pacific Coast of México.

Two major routes are potentially available. Hydrochoerus could have followed a coastal route from further south in México northward along the coasts of Sinaloa and Sonora 
White et al. - new Pleistocene Hydrochoerus from California

to the mouth of the Colorado River where they would have travelled inland into California and potentially made their way westward through the Salton depression and thence north along the Whitewater River drainage, finally reaching the San Luis Rey River in San Diego County. There are difficulties in envisioning this route, particularly once capybaras had reached the Colorado River, as there are stretches where overland dispersal would have been necessary and permanent sources of water scarce or unknown.

A second route also starts with capybaras moving north along the coasts of Sinaloa and Sonora, but then entering the major north or northeast flowing drainages which enter the Gulf of California, particularly the Rio Fuerte, Rio Mayo, Rio Yaqui, and the Rio Sonora (Fig. 3). We know that capybaras did travel north along the Rio Yaqui, and into the Rio Moctezuma, a distance of $350 \mathrm{~km}$ (220 miles) where they reached the site of Térapa in eastern Sonora (Mead et al. 2006) accompanied by crocodiles, to within $180 \mathrm{~km}$ (110 miles) of the México/USA border. It is easy to envisage them traveling further north into the San Simon drainage and thence to the Gila River, from where they could have reached downstream to the Colorado River and into California. Just such a route may well have been available for more than 2.5 million years, and used by the two previous lineages to disperse into northwestern México and the American Southwest: Phugatherium dichroplax appears in the latest Blancan in the San Simon drainage in Arizona in the 111 Ranch fauna during a short interval just below the Gauss/Matuyama Boundary, 2.58 Ma (Ahearn and Lance 1980; Galusha et al. 1984; Tomida 1987) and Neochoerus occidentalis into northwestern Sonora near the mouth of the Colorado River in the El Golfo fauna of latest Blancan or earliest Irvingtonian age (Carranza-Castañeda 2016). Whatever the identity of the Térapa capybara, it also followed this route in the Rancholabrean some 40-42 ka (Mead et al. 2006; Bright et al. 2010; Short et al. 2021). Until the discovery of SDSNH 50000 in San Diego County, we had no evidence that capybaras had penetrated into, or perhaps survived in, the Rancholabrean of New Mexico, Arizona, or California.

The Rio Yaqui is not the northern-most drainage which animals with southern affinities have taken to extend their distribution northwards. Remains of the Sabinal Frog (Leptodactylus melanonotus) were recovered from Rancho La Brisca, in the Rio Sonora drainage, some $240 \mathrm{~km}$ (150 miles) north of their present distribution on the Rio Yaqui (Van Devender et al. 1985). A record of the Sabinal Frog from near Hermosillo, also in the Rio Sonora drainage, is mentioned by Van Devender et al. (1985) and by Rorabaugh and Lemos-Espinal (2016), who also mention an unconfirmed sight record near Moctezuma on the Rio Yaqui drainage. It is reasonable to suggest that other taxa with southern affinities might have utilized the Rio Sonora and other drainages to disperse north.

What are we to make of this paucity of capybara remains in the Rancholabrean fossil record in Sonora, Baja California, Western Texas, New Mexico, and Arizona, with only a single record in Térapa, Sonora? Were capybaras rare or otherwise absent? We suggest that several factors are responsible. First and foremost, very few late Pleistocene sites in Sonora have been intensively sampled, with adequate efforts for the recovery of microfauna. Térapa and Rancho La Brisca are, to our knowledge, the only two sites where micromesh screen washing has been employed and reported. No capybara was recovered from Rancho La Brisca (Van Devender et al. 1985). White et al. (2010) documented 60 sites known to have produced Pleistocene (Irvingtonian and Rancholabrean) fossils in Sonora. Several of these sites have the potential to produce significant faunal remains if intensively sampled; for example, Chinobampo, in the Río Mayo drainage appears to have been formed in much the same way as Térapa, with a classic Rancholabrean fauna including Bison, Equus, and Glyptotherium. However, Chinobampo may date somewhat later than does Térapa, given the purported presence of human skeletal material in association with the Rancholabrean faunal remains (White et al. 2010).

The mouths of the rivers emptying into the Gulf of California in Sinaloa and southern Sonora have thorn scrub habitats and tend to be associated with more or less extensive growth of mangrove trees today. The northern-most mangrove swamp on the Sonoran side of the Gulf of California is the one located just south of Cerro Tepopa at the Sargento Estuary. There is an extinct estuary further north at the mouth of the Rio San Ignacio just south of the Comcaac village of Desemboque de los Seris. There is then a gap of some $50 \mathrm{~km}$ (30 miles) where another extinct estuary is located at Puerto Libertad. The areas around all three of these estuaries (Punta Sargento, Rio San Ignacio, and Puerto Libertad) should be carefully examined to see if fossil-bearing sediments can be located. Bathymetric data in the vicinity of these localities suggest that the glacial maximum shorelines would not have been far from the present-day shoreline, so the chance of significant deposits being preserved, and accessible, is much greater than father north, where the glacial maximum shoreline was distinctly farther from the present-day shoreline (Fig. 3). It is possible that the San Diego County record of Hydrochoerus came north along the coast of México, then along the Pacific coast of Baja California prior to the separation of Baja from mainland México and the formation of the Gulf of California, and into what is now California. Geologic evidence, however, suggests that the Gulf of California began to appear as early as about $10 \mathrm{Ma}$ as Baja California rifted north and west from mainland México 
towards its present position (Dolby et al. 2015). The Gulf of California was nearly at its present length but narrower, by $6 \mathrm{Ma}$ (Dolby et al. 2015). This is well before any record of capybaras in México at about 3.3-3.8 Ma (CarranzaCastañeda 2016). The opening of the Gulf of California increased summer monsoonal rainfall in mainland Sonora and Sinaloa, marking a northern expansion of humid, subtropical thorn forest vegetation along the coasts of Sinaloa and Sonora (Chapin 2008), which would have provided an ideal corridor along which taxa with southern affinities, such as capybaras, crocodiles, glyptodonts, and pampatheres could have dispersed. This further supports our contention that it is along the Gulf of California coasts of Sinaloa and Sonora where evidence of the dispersal of Hydrochoerus northward should be sought if the coastal dispersal route, rather than an interior route, was involved in capybaras reaching coastal southern California in the late Pleistocene.

\section{CONCLUSIONS}

Hydrochoerus hesperotiganites represents a new species of capybara from San Diego County, California USA. The new species is the only confirmed record of fossil Hydrochoerus in North America and is the northwestern-most record in North America during the Rancholabrean.

Future areas of work should include the search for fossil Hydrochoerus along the coast of northwestern Mexico. Descriptions of the auditory region, particularly of Neochoerus, are needed. A larger sample of extant capybaras needs to be examined in detail, especially of the smaller species, $H$. isthmius, which comprises the geographically closest population of Hydrochoerus to the new California species, and presumably to any as yet undiscovered geographically intermediate forms in Central America.

\section{ACKNOWLEDGEMENTS}

We thank Sandra L. Swift for her assistance in producing many of the photographs and providing her assistance and advice on those taken by RSW. Her considerable skills greatly improved and enhanced the usefulness of this paper. Andreas Kerner provided fossil capybara comparative material from his private collection. Steve and Suzanne Hutchens donated a capybara M3 from Inglis 1A to the Mammoth Site collection. C. Jass and R. Holmes provided useful reviews which greatly improved the manuscript. Matthew C. Pailes, Department of Anthropology, University of Oklahoma, graciously provided the base map and adapted it for our use, adding features at our request to produce the final map. Staff at the San Diego Zoo graciously permitted access to the capybara exhibit in 2008, before it was opened to the public, so that we could observe living capybaras in detail. RSW would like to acknowledge the as- sistance of his late wife, Carolyn Torrey White, for her help and her insistence that I finish this and other projects.

\section{LITERATURE CITED}

Aeschbach, M., J.D. Carillo and M.R. Sanchez. 2016. On the growth of the largest living rodent: postnatal skull and dental shape changes in capybara species (Hydrochoerus spp.). Mammalian Biology 81:558-570.

Ahearn, M.E. 1981. A revision of the North American Hydrochoeridae. Unpublished Master's Thesis, University of Florida, Gainesville, 99 pages.

Ahearn, M.E., and J.F. Lance. 1980. A new species of Neochoerus (Rodentia: Hydrochoeridae) from the Blancan (late Pliocene) of North America. Proceedings of the Biological Society of Washington 93:435-442.

Albright, L.B., A.E. Sanders, R.E. Weems, D.J. Cicimurri, and J. L. Knight. 2019. Cenozoic vertebrate biostratigraphy of South Carolina, U.S.A., and additions to the fauna. Bulletin of the Florida Museum of Natural History 57:77-236.

Alvarez, T. 1971. Variación de la figura occlusal del premolar inferior en carpinchos fósiles (Rodentia:Hydrochoeridae) de Jalisco, México. Instituto Nacionale de Antropología e Historia, Serie Investigaciones 21:35 pp.

Baskin, J.A. and R.G. Thomas. 2007. South Texas and the Great American Interchange. Gulf Coast Association of Geological Societies Transactions 57:37-45.

Baskin, J., P.D. Gervais, and C.J. Gervais. 2020. A late Pleistocene capybara (Rodentia, Caviidae, Hydrochoerinae) from near Houston, Texas, USA, with a brief review of North American fossil capybaras. Proceedings of the Academy of Natural Sciences of Philadelphia 167:57-68.

Bowdich, T.E. 1821. An analysis of the natural classifications of the Mammalia for the use of students and travelers. Paris, J. Smith, 115 pp.

Bright, J., D.S. Kaufman, S.L. Forman, W.C. McIntosh, J.I. Mead, and A. Baez. 2010. Comparative dating of a Bisonbearing late-Pleistocene deposit, Térapa, Sonora, México. Quaternary Geochronology 5:631-643.

Brisson, M.J. 1762. Regnum animale in classes IX distributum sive synopsis methodica. Edition altera auctior. Leiden, Theodorum Haak, 296 pp.

Cabrera, A. 1961. Catálogo de los mamíferos de América del Sur. Revista del Museo Argentino de Ciencias Naturales "Bernardino Rivadavia" Ciencias Zoológicos 4:309-732.

Carbot-Chanona, G, J. Eng-Ponce, and L.E. Gomez-Perez. 2020. Description of Neochoerus specimens from the late Pleistocene (Rancholabrean) of Chiapas, and comments on the taxonomic identity of the fossil capybaras from other Mexican localities. Boletín de la Sociedad Geológica Mexicana 72 (1), unpaginated.

Carranza-Castañeda, O. 2016. Roedores caviomorphos (Rodentia Hydrochoeridae) del Blancano temprano-tardío - Irvingtoniano 
White et al. - new Pleistocene Hydrochoerus from California

de los estados de Guanajuato, Jalisco y Sonora, México: relación con Phugatherium dichroplax. Revista Mexicana de Ciencias Geológicas 33:297-315.

Carranza-Castañeda, O. and W.E. Miller. 1988. Reodores aviomorfos de la Mesa Central de México, Blancano Temprano (Plioceno Tardío) de la Fauna Local Rancho Viejo, Estado de Guanajuato. Universidad Nacional Autónoma de México, Instituto de Geológia, Revista 7:182-199.

Ceballos, G., J. Arroyo-Cabrales and E. Ponce. 2010. Effects of Pleistocene environmental changes on the distribution and community structure of the mammalian fauna of México. Quaternary Research 73:464-473.

Chapin, C.E. 2008. Interplay of oceanographic and paleoclimate events with tectonism during middle to late Miocene sedimentation across the southwestern USA. Geosphere 4(6):976-991.

Croxen, F.W., C.A. Shaw, and D.R. Sussman. 2007. Pleistocene geology and paleontology of the Colorado River Delta at Golfo de Santa Clara, Sonora, México; pp. 84-89 in: R.E. Reynolds (ed.), Wild, Scenic \& Rapid - a Trip Down the Colorado River Trough. California State University, Desert Studies Consortium and LSA Associates, Inc.

Deméré, T.A., K.A. Randall, B.O. Riney, and S.A. Siren. 2013. Discovery of remains of an extinct giant bison (Bison latifrons) in upper Pleistocene (Rancholabrean) fluvial strata in the San Luis Rey River Valley, San Diego County, California, USA; pp. 123-144 in B.J. Olson (ed.), San Luis Rey on display: geoscience in northern San Diego County. San Diego Association of Geologists 2013 Field Trip Guidebook. Sunbelt Publications, San Diego.

Dolby, G.A., S.E.K. Bennett, A. Lira-Noriega, B.T. Wilder and A. Munguia-Vega. 2015. Assessing the geological and climatic forcing of biodiversity and evolution surrounding the Gulf of California. Journal of the Southwest 57:391-456.

Doley, P, P.C. Kalita, A. Kalita, O.P. Choudhary, and H. Das. 2018. Morphological study on the skull of wild boar of Mizoram (Sus scrofa). International Journal of Livestock Research 8(5), unpaginated.

Frazier, M.K. 1981. A revision of the fossil Erethizontidae of North America. Bulletin of the Florida State Museum 27:1-76.

Galusha, T., N.M. Johnson, E.H. Lindsay, N.D. Opdyke, and R.H. Tedford. 1984. Biostratigraphy and magnetostratigraphy, late Pliocene rocks, 111 Ranch, Arizona. Geological Society of America Bulletin 95:714-722.

Gill, T. 1872. Arrangements of the families of mammals with analytical tables. Smithsonian Miscellaneous Collections 11:1-198.

Goldman, E.A. 1912. New mammals from eastern Panama. Smithsonian Miscellaneous Collections 60:1-18.

Gorosabel, A., M.J. Corriale, and D. Loponte. 2017. Methodology for the estimation of the age categories of Hydrochoeris hydrochaeris (Rodentia, Hydrochoeridae) through the cranial and femur morphology. Mammalia 81(1):83-90.

Gray, J.E. 1821. On the natural arrangement of vertebrose animals. London Medical Repository 15:296-310.
Gray, J.E. 1825. An outline of an attempt at the disposition of the Mammalia into tribes and families with a list of the genera appertaining to each tribe. Annals of Philosophy (new series) 10:337-344.

Guthrie, D.A. 2012. Avian material from Rancho del Oro, a Pleistocene locality in San Diego County, California. Bulletin of the Southern California Academy of Science 109:1-7.

Hernandez-Junquera, A. 1977. Fauna local Laguna de la Media Luna, Pleistoceno Tardío, Municipio de Rio Verde, San Luis Potosí, México. Universidad Nacional Autónoma de México Bachelor thesis, 102 pp.

Hooijer, D.A. 1959. Fossil rodents from Curacao and Bonaire. Studies on the fauna of Curacao and other Caribbean islands 9:1-27.

Hulbert, R.C. Jr. 2010. A new early Pleistocene tapir (Mammalia: Perissodactyla) from Florida, with a review of Blancan tapirs from the state. Bulletin of the Florida Museum of Natural History 49:67-126.

Hulbert, R.C., S.C. Wallace, W.E. Klippel, and P.W. Parmalee. 2009. Cranial morphology and systematics of an extraordinary sample of the late Neogene dwarf tapir, Tapirus polkensis (Olsen). Journal of Paleontology 83:238-262.

Kerber, L., and A.M. Ribiero. 2011. Capybaras (Rodentia: Hystrichognathi: Hydrochoeridae) from the late Pleistocene of southern Brazil. Neues Jahrbuch für Geologie und Paläontologie Abhandlungen 261:1-18.

Kraglievich, L. 1930. La Formación Friaseana del Río Frías, Río Fénix, Laguna Blanca, etc., y su fauna de mamíferos. Physis 10:127-161.

Kraglievich, L. 1941. Morfología normal y morfogénesis de los molars de los carpinchos y caracteres filogénticos de este grupod de roedores (La primera parte en colaboración con el Sr. Lorenzo J. Parodi). Obras de Geología y Paleontología 3:438-484.

Kurtén, B., and E. Anderson. 1980. Pleistocene Mammals of North America. Columbia University Press, 442 pp.

Leidy, J. 1887. Toxodon and other remains from Nicaragua, C. A. Proceedings of the Academy of Natural Sciences of Philadelphia 38:275-277.

Lindsay E. 1984. Late Cenozoic mammals from northwestern México. Journal of Vertebrate Paleontology 4:208-215.

Lucas, S.G. 2008. Late Cenozoic fossil mammals from the Chapala Rift Basin, Jalisco, México. New Mexico Museum of Natural History and Science Bulletin 44:39-49.

Lucas, S.G., R. Garcio, E. Espinoza, G. Alvarado, L. Hurtado de Mendoza, and E. Vega. 2008. The fossil mammals of Nicaragua. New Mexico Museum of Natural History and Science Bulletin 44:417-429.

Lucas, S.G., J.E. Romero, O.J. Vásquez, and G.E. Alvarado. 2021. The fossil vertebrates of Guatemala. Revista Geológica de América Central 66:1-32.

MacPhee, R.D.E., R. Singer, and M. Diamond. 2000. Late Cenozoic land mammals from Grenada, Lesser Antilles IslandArc. American Museum Novitates 3302:1-20. 
McDonald, H.G., and S.L. Davila A. 2017. Mammoths in Central America: New records from Guatemala. Quaternary International 443:121-128.

Mead, J.I., A. Baez, S.L. Swift, M.C. Carpenter, M. Hollenshead, N.J. Czaplewski, D.W. Steadman, J. Bright, and J. Arroyo Cabrales. 2006. Tropical marsh and savanna of the late Pleistocene in Northeastern Sonora, México. The Southwestern Naturalist 51:226-259.

Mead, J.I., S.L. Swift, R.S. White, H.G. McDonald, and A. Baez. 2007. Late Pleistocene (Rancholabrean) glyptodonts and pampathere (Xenarthra, Cingulata) from Sonora, Mexico. Revista Mexicana de Ciencias Geológicas 24:439-449.

Mones, A. 1974. Estudios sobre la familia Hydrochoeridae (Rodentia), III. Osteología comparada de la región auditiva de Hydrochoerus Brisson con formas affines. Ameghiniana 11:39-57.

Mones, A. 1991. Monographía de la familia Hydrochoeridae (Mamalia: Rodentia). Courier Forschunginstitut Senckenberg 134:1-235.

Morgan, G.S. 2005. The Great American Biotic Interchange in Florida. Bulletin of the Florida Museum of Natural History 45:271-311.

Morgan, G.S. 2008. Vertebrate fauna and geochronology of the Great American Biotic Interchange in North America, in Neogene mammals. New Mexico Museum of Natural History and Science Bulletin 44:93-140.

Morgan, G. S., and S.D. Emslie. 2010. Tropical and western influences in vertebrate faunas from the Pliocene and Pleistocene of Florida. Quaternary International 217:143-158.

Morgan, G.S., and R.C. Hulbert Jr. 1995. Overview of the geology and vertebrate paleontology of the early Pleistocene (early Irvingtonian) Leisey Shell Pit Local Fauna, Hillsborough County, Florida. Florida Museum of Natural History Bulletin 37:1-92.

Morgan, G.S., and J.A. White. 1995. Small mammals (Insectivora, Lagomorpha, and Rodentia) from the early Pleistocene (early Irvingtonian) Leisey Shell Pit Local Fauna, Hillsborough County, Florida. Florida Museum of Natural History Bulletin 37:397-461.

Nunez, E.E., B.J. MacFadden, J.I. Mead, and A. Baez. 2010. Ancient forests and grasslands in the desert: diet and habitat of late Pleistocene mammals from northcentral Sonora, México. Palaeogeography, Palaeoclimatology, Palaeoecology 301:56-63.

O'Dea, A., and 34 other authors. 2016. Formation of the Isthmus of Panama. Science Advances 2: e1600883 (11 pages).

Ojasti, J. 1973. Estudio Biológico del Chiguirre o Capibara. Fondo Nacional de Investigaciones Agropecuarias (FONAIAP), Caracas, Venezuela, 273 pp.

Ojasti, J. 2011. Estudio Biológico del Chigüire o Capibara. 2nd edition. Editorial Equinoccio. Caracas, Venezuela, 353 pp.

Perez, M.E., M.C. Vallejo-Pareja, J.D. Carrillo, and C. Jaramillo 2017. A new Pliocene capybara (Rodentia, Caviidae) from northern South America (Guajira, Columbia) with its implications for the Great American Biotic Interchange. Journal of Mammalian Evolution 24:111-125.
Perez-Crespo, V.A., J. Arroyo-Cabrales, L.M. Alva-Valdiva, P. Morales-Puente, E. Cienfuegos-Alvarado, F.J. Otero, and P. Ochoa-Castillo. 2014. La paleodieta de cinco especies de mammíferos herbveríos rancholabreanos de Valsequillo (Puebla) México. Revista Chilena de Antropología 30:76-82.

Peters, R.B. 1951. A preliminary report on the geology of Lake Chapala (México) and the possibility of its being the site of late Pleistocene man. Yearbook Association of Pacific Coast Geographers 13:48.

Pichado, M. 1997. Valsequillo biostratigraphy: new evidence for pre-Clovis date. Anthropologgischer Anzeiger 53:233-246.

Prado, J.L., A. Cerdeño, and S. Roig-Juñent. 1998. The giant rodent Chapalmatherium from the Pliocene of Argentina: New remains and taxonomic remarks on the family Hydrochoeridae. Journal of Vertebrate Paleontology 18:788-798.

Rorabaugh, J.C., and J.A. Lemos-Espinal. 2016. A Field Guide to the Amphibians and Reptiles of Sonora, México. Eco Wear and Publishing Co. Rodeo, New Mexico, 688 pp.

Rufolo, S.J. 1998. Taxonomy and significance of the fossil mammals of Lake Chapala, Jalisco, México. PhD dissertation, Brigham Young University, 292 pp.

Rusconi, C. 1939. El premolar inferior de los grandes carpinchos extinguidos. Anales de la Sociedad Cientifica Argentina 128:233-239.

Sanders, A.E. 2002. Additions to the Pleistocene mammal faunas of South Carolina, North Carolina, and Georgia. Transactions of the American Philosophical Society 92:1-152

Short, R.A., L.G. Emmert, N.A. Famoso, J.M. Martin, J.I. Mead, S.L. Swift, and A. Baez. 2021. Paleobiology of a large mammal community from the late Pleistocene of Sonora, México. Quaternary Research 202:1-13.

Simpson, G.G. 1928. Pleistocene mammals from a cave in Citrus County, Florida. American Museum Novitates 328:1-16.

Simpson, G.G. 1930. Additions to the Pleistocene of Florida. American Museum Novitates 406:1-14.

Tomida, Y. 1987. Small Mammal Fossils and Correlation of Continental Deposits, Safford and Duncan Basins, Arizona, USA. National Science Museum, Tokyo, 141 pp.

Van Devender, T.R., A.M. Rea, and M.I. Smith. 1985. The Sangamon interglacial vertebrate fauna from Rancho la Brisca, Sonora, México. Transactions of the San Diego Society of Natural History 21:23-55.

Vucetich, M.G., C.M. Deschamps, Olivares, A.I., and M.T. Dozo. 2005. Capybaras, size, shape and time: a model kit. Acta Palaeontologica Polonica 50:259-272

Vucetich, M.G., C.M.Deschamps, and M.E. Perez. 2013. Paleontology, evolution and systematics of capybara; pp. 39-59 in J.R. Morira, K. Ferraz, E. Herrera and D. Macdonald (eds). Capybara: Biology, Use and Conservation of an Exceptional Neotropical Species. Springer Science Media, New York.

Vucetich, M.G., C.M. Deschamps, M.E. Perez, and C.I. Montalvo. 2014. The taxonomic status of the Pliocene capybaras (Rodentia) Phugatherium Ameghino and Chapalmatherium Ameghini. Ameghiniana 51:173-183. 
Vucetich, M.G., C.M. Deschamps, and M.E. Perez. 2015. The first capybaras (Rodentia, Caviidae, Hydrochoerinae) involved in the Great American Biotic Interchange. Ameghiniana 52:342-333.

Webb, S.D. 1974. Chronology of Florida Pleistocene mammals; pp. 5-31 in S.D. Webb (ed). Pleistocene Mammals of Florida. The University Press of Florida, Gainesville, 270 pp.

Webb, S.D. 1978. A history of savanna vertebrates in the New World. Part II: South America and the Great Interchange. Annual Review of Ecology and Systematics 9:393-426.

Webb, S.D., and S.C. Perigno. 1984. Late Cenozoic vertebrates from Honduras and El Salvador. Journal of Vertebrate Paleontology 4:237-254.
White, R.S., J.I. Mead, A. Baez, and S.L. Swift. 2010.

Localidades de vertebrados fósiles de Neógeno (Mioceno, Plioceno y Pleistoceno): Una evaluación preliminar de la biodiversidad del pasado; pp. 51-72 in F.E. Molina-Freaner and T.R. Van Devender (eds). Diversidad biológica de Sonora. UNAM, México.

Woodburne, M.O. 2010. The Great American Biotic Interchange: Dispersals, tectonics, climate, sea level and holding pens. Journal of Mammalian Evolution 17:245-264. 